\title{
Litigation and Social Capital: Divorces and Traffic Accidents in Japan
}

\section{Citation}

J. Mark Ramseyer, Litigation and Social Capital: Divorces and Traffic Accidents in Japan (Harvard John M. Olin Center for Law, Economics, and Business, Discussion Paper No. 727, Aug. 2012).

\section{Published Version}

http://www.law.harvard.edu/programs/olin_center/papers/pdf/Ramseyer_727.pdf

\section{Permanent link}

http://nrs.harvard.edu/urn-3:HUL.InstRepos:16882983

\section{Terms of Use}

This article was downloaded from Harvard University's DASH repository, and is made available under the terms and conditions applicable to Other Posted Material, as set forth at http:// nrs.harvard.edu/urn-3:HUL.InstRepos:dash.current.terms-of-use\#LAA

\section{Share Your Story}

The Harvard community has made this article openly available.

Please share how this access benefits you. Submit a story.

Accessibility 


\title{
HARVARD
}

JOHN M. OLIN CENTER FOR LAW, ECONOMICS, AND BUSINESS

\author{
LITIGATION AND SOCIAL CAPITAL: \\ DIVORCES AND TRAFFIC ACCIDENTS \\ IN JAPAN
}

\section{J. Mark Ramseyer}

Discussion Paper No. 727

$08 / 2012$

\author{
Harvard Law School \\ Cambridge, MA 02138
}

This paper can be downloaded without charge from:

The Harvard John M. Olin Discussion Paper Series:

http://www.law.harvard.edu/programs/olin_center/

The Social Science Research Network Electronic Paper Collection: http://ssrn.com/ 
Address correspondence to:

J. Mark Ramseyer

Harvard Law School

Cambridge, MA 02138

ramseyer@law.harvard.edu

617-496-4878

\title{
Litigation and Social Capital: Divorces and Traffic Accidents in Japan
}

\author{
By J. Mark Ramseyer*
}

\begin{abstract}
Are litigation rates higher where social capital is low? Using prefecture-level data, I ask whether Japanese in communities with high levels of "social capital" more readily settle their divorce and traffic accident disputes outof-court. Although litigation rate studies often measure suits per capita, the more appropriate measure may involve suits per "dispute." For many categories of disputes we lack reliable data about the numbers of disputes involved, but for divorce and traffic accidents we do have those numbers. Using these data, I find that couples in communities with low social capital are more apt to divorce, and so are those in poorer communities. Conditional on divorce, however, couples in low social-capital communities are not more likely to litigate the terms of their divorces. Note that litigation rates for divorce are higher in wealthier and bettereducated communities, but unrelated to the availability of an attorney.

I contrast this situation with disputes over serious traffic accidents. In these disputes, whether a party sues depends crucially on the availability of an attorney. Social capital also seems to reduce the litigation rate, but wealth and education (beyond their effect through attorney availability) do not matter.
\end{abstract}

* Mitsubishi Professor of Japanese Legal Studies, Harvard University. I gratefully acknowledge the helpful suggestions of Wered ben Sade, Tom Ginsburg, and Glenn Hoetker, and the generous financial assistance of the Harvard Law School. 
Litigiousness "is born of a breakdown in community," Jethro Lieberman $(1983,187)$ once wrote. We sue because we no longer trust each other to pay voluntarily. We attack because we no longer think anyone will help us when we need it. Once upon a time, we cooperated first and reneged only when ourselves exploited. No longer. Rather than play the venerable tit-for-tat, we defect from the start. We sue because, to use Robert Putnam's (2000) phrase, we have destroyed our stock of "social capital." We defect because we "bowl alone."

Or so we tell ourselves. And in contrast to this (perhaps mythically) anomic and litigious America, we have long presented Japan as a relatively cooperative world. Japanese do indeed seem more cooperative than Americans, on any of several measures. Yet even within Japan itself, those in some communities more often litigate than others. Might this internal variation in the way Japanese use courts reflect variations in the level of Putnam's social capital?

Plausibly, social capital could affect the use of the courts in two very different ways. First, communities with high levels of social capital might have fewer disputes. People might drive more carefully. They might keep more of their promises. They might steal less property. If social capital is high, people might wrong each other less. Suffering fewer wrongs, they might file fewer suits.

Second, given a fixed stock of disputes, people in communities with higher levels of social capital might take a smaller fraction of those disputes to court. They might be more willing to talk to each other. They might be able to reach agreement more readily. They might cut enforceable deals more easily.

In the article that follows, I use the diversity within Japan to explore this possibly double role that social capital might play. I ask whether social capital correlates with the number of divorces. With the number of divorces held constant, I ask whether it correlates with the tendency to negotiate the divorce out-of-court. I find that couples in communities with high levels of social capital do divorce less frequently. With the number of divorces held constant, however, couples in communities with high social capital are more -- not less -- likely to litigate their divorce. The availability of attorneys has no effect on whether they litigate. I then contrast these these results to litigation over serious traffic accidents: there, social capital does reduce litigation rates, and the availability of an attorney matters even more strongly.

Too often, in discussing "litigation rates" we conflate the question of (a) what causes the disputes we observe, with the question of (b) given those disputes, what causes people to litigate them? Typically, in other words, we define the litigation rate as a variation on (litigated suits)/(population). Yet that fraction itself combines two very different components: (litigated suits)/(total disputes), and (total disputes)/(population). These component fractions raise conceptually distinct issues. Where one factor might increase the number of disputes in a community, another might increase the fraction of those disputes that people choose to litigate. In this article, I disentangle the two questions.

I begin by summarizing the classic model of litigation and settlement (Sec. I.A.) and the literature on social capital (Sec. I.B.). In Sec. I.C. I ask how one might incorporate social capital 
into the classic model, and explore the colinearities among social capital, wealth, and education. I then turn to the principal empirical project. I discuss my variables in Sec. II, and the results in Sec. III (the correlates of the decision about whether to litigate a divorce) and Sec. IV (the correlates of the decision about whether to divorce in the first place). I contrast these outcomes with the role that social capital plays in traffic accident litigation in Sec. V.

\section{Litigation and Social Capital}

A. The Classic Model:

Begin with the standard -- now classic -- model of litigation and settlement (Landes, 1971; Posner, 1973). Stripped of refinements, it posits that plaintiffs can profitably settle their claims for any amount $\left(\mathrm{P}_{\min }\right)$ greater than the estimated value they place on their claim $\left(\mathrm{V}_{\mathrm{p}}\right)$, less their expected litigation costs $\left(\mathrm{L}_{\mathrm{p}}\right)$ but plus their expected settlement costs $\left(\mathrm{S}_{\mathrm{p}}\right)$ :

$$
\mathrm{P}_{\min }=\mathrm{V}_{\mathrm{p}}-\mathrm{L}_{\mathrm{p}}+\mathrm{S}_{\mathrm{p}}
$$

Analogously, defendants can profitably pay in settlement any amount $\left(D_{\max }\right)$ less than the estimated value they place on the plaintiff's claim $\left(\mathrm{V}_{\mathrm{d}}\right)$, plus their own expected litigation costs $\left(\mathrm{L}_{\mathrm{d}}\right)$ and less their expected settlement costs $\left(\mathrm{S}_{\mathrm{d}}\right)$ :

\section{$\mathrm{D}_{\max }=\mathrm{V}_{\mathrm{d}}+\mathrm{L}_{\mathrm{d}}-\mathrm{S}_{\mathrm{d}}$}

The parties face a range of mutually advantageous settlements when $\mathrm{P}_{\min }<\mathrm{D}_{\max }$. They have no choice but to litigate when $\mathrm{P}_{\min }>\mathrm{D}_{\max }$. The more optimistic they each might be, the more likely $\mathrm{P}_{\min }>\mathrm{D}_{\max }$ and the more likely they will litigate. The greater the expected costs of litigation, the more likely they will settle. And the lower the cost of settlement, the more likely they will settle.

Consider now the effect of education and wealth. Educated disputants will find it easier than others to manipulate complex bureaucracies. They will find it easier to understand elaborate legal rules. In effect, they face lower litigation costs, and should litigate a larger fraction of their disputes.

Richer parties should also litigate more of their disputes. By the terms of the classic model, the parties can settle if but only if

$$
\mathrm{V}_{\mathrm{p}}-\mathrm{L}_{\mathrm{p}}+\mathrm{S}_{\mathrm{p}}<\mathrm{V}_{\mathrm{d}}+\mathrm{L}_{\mathrm{d}}-\mathrm{S}_{\mathrm{d}}
$$

Rearrange the terms, and

$$
\mathrm{V}_{\mathrm{p}}-\mathrm{V}_{\mathrm{d}}<\left(\mathrm{L}_{\mathrm{p}}+\mathrm{L}_{\mathrm{d}}\right)-\left(\mathrm{S}_{\mathrm{p}}+\mathrm{S}_{\mathrm{d}}\right)
$$

$\mathrm{V}_{\mathrm{p}}$ and $\mathrm{V}_{\mathrm{d}}$ each represent a sum of estimated probabilities (the odds that the plaintiff will win) times possible judgments (the amounts the plaintiff might collect if he does win). Hold constant the estimated probabilities but increase the range of possible judgments, and $V_{p}-V_{d}$ will rise.

Increase the amount at stake, in other words, and the probability of litigation will rise. Although disputants do rationally invest more resources in high-stakes disputes than low, they do not usually increase litigation costs dollar-for-dollar with the amount at stake. As a result, they will more likely face a viable settlement window in a small-stakes dispute than a large. Given that rich disputants will have more high-stakes disputes than poor, rich disputants will have more disputes that they cannot cost-effectively settle. ${ }^{1}$

\section{B. Social Capital:}

1. Introduction. -- According to several prominent scholars, where social capital is high people trust each other to cooperate and keep their word. They rely on communal norms to

\footnotetext{
${ }^{1}$ As found, for example, in Eisenberg, et al. (2012); Ginsburg \& Hoetker (2006).
} 
enforce any agreements they negotiate. When the stock of capital falls, they lose that trust. Unable anymore to enforce their agreements through social ties, they turn to law, lawyers, and courts. Where social capital is high, Blanche Dubois depends on the kindness of strangers. Where social capital is low, she sues.

2. Social capital. -- Lieberman $(1983,186)$ put the tie between social capital and litigation most starkly:

Litigiousness is not a legal but a social phenomenon. It is born of a breakdown in community, a breakdown that exacerbates and is exacerbated by the growth of law. ... [U]ntil there is a consensus on fundamental principles, the trust that is essential to a selfordering community cannot be.

Social capital falls; litigation climbs.

Putnam (2000) explained the connection as a function of the trust that comes from a dense network of social ties and obviates the need for the more costly legal apparatus. "[F]ormal contracts, courts, litigation, adjudication, and enforcement by the state" are, he writes (id., 144145), "one alternative to generalized reciprocity and socially embedded honesty." Since 1970, that expectation of generalized reciprocity has fallen in the U.S., and "informal understandings no longer [seem] adequate or prudent" (id., 147).

Instead, Putnam $(2000,21)$ argued, modern Americans manipulate legal processes to their detriment:

A society characterized by generalized reciprocity is more efficient than a distrustful society, for the same reason that money is more efficient than barter. If we don't have to balance every exchange instantly, we can get a lot more accomplished. ... When economic and political dealing is embedded in dense networks of social interaction, incentives for opportunism and malfeasance are reduced.

As Elinor Ostrom $(1998,16)$ put it, groups can "fail to achieve mutually productive benefits due to their lack of trust in one another or to the lack of arenas for low-cost communication, institutional innovation, and the creation of monitoring and sanctioning rules."

Robert Ellickson (1991) made much the same claim in his study of Shasta County farmers. "[T]he more close knit a group," argued Ellickson (1991, 250), the more successful it will be at generating and enforcing utilitarian norms to govern internal disputes." Because members will consider their norms superior to to the law, close-knit groups will tend (id., 250) "to have controller-selecting norms that discourage members from taking intermember disputes into the legal system." Concluded Ellickson (1991, 251):

Groups with large or transitory membership are usually not close-knit and cannot rely as much on informal social control. As a result, resort to the legal system tends to be tolerated more in industrialized than in preindustrial cultures, and more in large cities than in small towns.

In his controversial Coming Apart, Charles Murray (2012) argues that social capital is not disappearing in the U.S. across the board. Instead, it remains intact in professional communities, but has almost entirely vanished among the working class. He calls the former "Belmont," after the affluent Boston suburb, and the latter "Fishtown," after the working class Philadelphia neighborhood of that name. In America's Belmonts, social capital remains high, writes Murray - and people read the newspaper, vote, attend churches and synagogues, volunteer at the schools, marry, bear children within marriage, and stay married; in Fishtown, social capital has vanished. 
With social capital high, in Belmont people keep their promises; with the social glue gone, in Fishtown they rely on partners at their peril. In Belmont, people trust; in Fishtown, they cheat.

3. Law \& social norms. -- Legal scholars discussed several of these themes in the "law \& social norms" literature. Ellickson $(1998,546)$ himself noted at the time that Putnam's social capital was "analogous to a set of adaptive norms." He and others noted several points relevant here. Fist, as Ellickson (1998, 546; 1990) put it, "informal systems of control" are "especially" important "where interacting parties have a continuing relationship" at stake. If a population is less stable, norms are less secure.

Second, people follow norms to retain the chance to trade. Communities enforce their norms, wrote Richard Posner, if they can tie them to an "implicit threat of ostracism, that is, of refusal of advantageous transactions." ${ }^{2}$ If people engage in fewer transactions with each other, norms are less secure.

Third, gossip matters. "Norms and rules, whether publicly or privately created, embody and convey information," explained Avery Katz: ${ }^{3}$

They cannot be followed unless information is transmitted regarding their substantive content; they cannot be enforced unless information is transmitted regarding who has obeyed them, who has violated them, and who is to impose any associated punishment or reward.

If people do not know what their neighbors do, norms are less secure.

C. Modeling Social Capital:

1. Introduction. -- Preliminarily, note the obvious: social capital appears nowhere in the classic model of litigation and settlement. The model is not about trust or generalized reciprocity. When Robert Mnookin and Lewis Kornhauser (1979) first applied the model to divorce, they did not try to introduce social capital either. Instead, they focused on the way court-enforceable rules shape the agreements couples reach out of court. They focused, as they inimitably put it, on the way that couples "bargain in the shadow of the law."

To be sure, one could add social capital to the model -- if one wanted. The question is whether one should want. Take a few of the simplest variations. Communities with high levels of social capital maintain wide-ranging and swift channels of communication. Necessarily, they have lower $S_{p}$ and $S_{d}$. Communities with high levels of social capital can cheaply punish members who renege on their agreements. By freeing couples from some of their worries about enforceability, they again lower $S_{p}$ and $S_{d}$. Some tightly bound communities (think Amish) maintain norms against litigating disputes. If they punish those who sue, the expected punishment could enter the model as an element subtracted from $\mathrm{P}_{\min }$ and added to $\mathrm{D}_{\max }$.

As with the debate over "law and social norms," the crucial question is empirical: how much do factors like these matter observationally? That we live in a socially constructed world has been a commonplace among freshman sociology courses for decades now. We take our norms and expectations -- our "preferences," in law \& economics -- from the communities within which we live and work. We know that. We could add those norms and expectations to the model, but is it worth it? In the end, the question is whether the model's increased explanatory power justifies the analytic complications it inevitably introduces.

\footnotetext{
2 (1997, 366); see also R. Posner \& Rasmusen (1999); R. Posner, (1998, 554); Akerlof (1976, 1980).

${ }^{3}$ (1996, 1749); see Akerlof (1976); Ellickson (1990: 180-81).
} 
2. Wealth and social capital. -- To explore the empirical ties between social capital and litigation rates, we will need necessarily to address several sets of colinearities. For example, social capital correlates with wealth -- and wealth affects litigation rates independently (see Sec. I.A.). Perhaps in some societies the two factors correlate negatively. One could imagine a world where the poor live in stable, closed rural villages, and the rich in anomic urban enclaves. One could imagine a society where poor communities enjoy high levels of social capital, and the rich have none.

One could imagine such a world, but in the modern U.S. we do not inhabit it. Neither does anyone in Japan (see Sec. III). As Putnam $(2000,193)$ put it, "[p]eople with lower incomes and those who feel financially strapped are much less engaged in all forms of social and community life than those who are better off." And as Murray (2012) explores at elaborate length, the American professional class lives within close networks that provide high levels of information, where members make massive investments in personal reputations, where they keep their families largely intact, and where they maintain tightly enforced norms of appropriate behavior. Those outside the professional class live with less of this.

3. Education and social capital. -- Social capital correlates with education too. Education also correlates with wealth, of course, and with litigation rates besides (see Sec. I.A.). Educated workers earn high incomes, and earning high incomes accumulate greater wealth. In part, they earn higher incomes because those incomes include a return on the investments they made in skills (think physics, calculus, and the ability to write a coherent paragraph) valued highly on the market. And in part they earn higher incomes because their level of education reflects a cognitive ability itself valued highly on the market. They were able to finish their education, in other words, because they brought an intellectual capacity that employers value independently of anything they learned in school.

Education also correlates with social capital independent of its correlation with wealth. Education, wrote Putnam (2000, 108), is "the strongest predictor of formal community involvement." Indeed (id., 118):

[H]ighly educated people ... are more likely to volunteer, to donate money, and to give blood. In particular, education is one of the most powerful predictors of virtually all forms of altruistic behavior, even after controlling for other possible predictors.

Again, Murray (2012) makes much the same observation. His social-capital-rich Belmont is not just wealthier than the social-capital-deprived Fishtown. It is also much more highly educated. Indeed, he sorts communities in part by income, but in part by education as well. Indeed, his claim that Americans segregate themselves by the cognitive ability reflected in their education embodies the very claim that makes his book so controversial.

\section{Japanese Divorce Litigation -- the Variables}

A. Introduction:

Social capital could affect the number of suits filed in two very different ways: it could affect the total number of disputes in the community, and it could affect the fraction of those disputes that people choose to litigate. Usually, we will know the number of disputes that people litigate. Often, however, we will have no idea how many underlying disputes they may have.

Suppose I throw a party for my students and one of them slips on our front porch and breaks a leg. No one will count the accident. If he sues, the court will count his claim. But if he 
never files the suit because I pay his expenses and add a few thousand dollars for good measure, no one else will ever know.

For the empirical exercise, the number of disputes is crucial. Scholars like Lieberman and Putnam suggest that people in communities with high social capital make less use of law, lawyers, and courts than people in communities with less social capital. To explore this claim, we need the total number of disputes. We cannot assume that the number of disputes stays constant. After all, by the very definition of social capital, we have good reason to think people in high-social-capital communities are more likely to drive carefully, to speak honestly, to keep their promises, to pay their bills, and to respect claims to property. Yet for most categories of disputes, we will not have that number of total disputes.

B. Divorce in Japan:

1. Introduction. -- About Japanese divorces, though, we do have the numbers necessary to estimate the two very different potential effects of social capital: (ii) suits/disputes, and (ii) disputes/population. In Japan, the city hall counts the total number of divorces. For this study, the figure represents the number of disputes. The courthouse counts the number of divorces that couples take to court. The ratio of divorces to marriages gives us the frequency of disputes. The ratio of litigated divorces to total divorces gives us the frequency of litigated resolutions.

2. The process. -- Most Japanese couples negotiate their divorces outside of the courts (Bryant, 1984). To marry in Japan, they enter their tie in the "family registry" (koseki) at their (usually local) city (or ward, village) hall. To divorce, they simply enter the event in the same registry. Provided they reach an agreement that satisfies them both, they can divorce with no more government involvement than a sheet of paper before a petty city hall bureaucrat.

Only couples that cannot agree on the terms of their divorce go to court. Once there, the judge will usually route them to a mediator. If they reach an agreement before the mediator, the judge will order the divorce on those negotiated terms. If they cannot agree, he will try the divorce claim in court.

3. The numbers. -- On a population of 126 million in 2010, Japanese concluded 700,000 marriages and 251,000 divorces. Of these divorces, the couples negotiated 220,000 out of court (kyogi). They reached 25,000 agreements through court mediation (chotei), and another 3,600 during court proceedings (wakai). The courts adjudicated 2,500 divorce disputes through trial. The ratio of divorces to marriages ranged from 28.9 percent in Tokyo to 45.2 percent in Aomori prefecture. The fraction of divorces negotiated as private agreements ranged from 80.4 percent in Yamagata prefecture to 92.1 percent in Okinawa (Kosei, 2010a).

3. Qualifications. -- For this study, I use prefecture-level data. Obviously, I would prefer a more finely grained dataset. Unfortunately, for most variables the information is not available below the prefectural level. I would also prefer an annual time series. Unfortunately again, many of the proxies for social capital are measured only occasionally at most.

Note that for American divorces, we have the number of disputes but not the number of claims litigated. Like Japanese couples, most American couples negotiate their divorce privately. As Mnookin \& Kornhauser put it $(1979,951)$, "the overwhelming majority of divorcing couples resolve distributional questions concerning marital property, alimony, child support, and custody without bringing any contested issue to court for adjudication." But even when they negotiate 
the deal on their own, most American couples still file their divorce in court for what Mnookin \& Kornhauser call the judicial "rubber stamp." American sources give the total number of divorces. Generally, however, they do not distinguish between those divorce decrees where the judge resolved significant questions, and those where he simply pressed the "rubber stamp."

\section{Dependent Variable:}

In the regressions below, I look for correlates of the decision by divorcing couples to settle out of court. I define that decision by:

Settlement rate: The number of divorces negotiated out of court (kyogi), divided by the total number of divorces. I take both figures from (Kosei, 2010a).

I include summary statistics in Table 1. I experiment with alternative measures of the decision to settle or litigate in Sec. III.E. I examine the (conceptually prior) decision to divorce at Sec. IV.

[Insert Table 1 about here.]

\section{Independent Variables -- Economic:}

To explore Japanese divorce litigation, I use three sets of independent variables. For reasons outlined earlier (Sec. I.A.), the classic model of litigation and settlement suggests that litigation rates should rise with both wealth and education. Accordingly, I begin with three proxies for the wealth of a community (this Sec. II.D.). I add several proxies for its educational level (Sec. E). I then turn to the inquiry at the heart of this study: proxies for the level of social capital (Sec. F).

Consider first the economic variables (summary statistics for these and other variables appear in Table 1):

Income PC: Mean annual salary in 2008 in 10,000 yen. I take the data from Nenshu (2012).

Savings PC: Mean bank deposits (but not other wealth) per capita in 2004, in 1000 yen. I take the data from Somu (2004).

High-income taxpayers PC: The number of high-income taxpayers per capita in 2004. The National Tax Office (which released the data through 2004) defined a high-income taxpayer as anyone who paid 10 million yen or more in income tax. To pay that much tax in 2004, a taxpayer would have needed to earn about $\$ 400,000$. If only the very wealthiest couples litigated their divorces, then this variable would explain litigation rates more fully than the other two economic variables. I take the data from Tokyo (2004). ${ }^{4}$

\section{E. Independent Variables -- Education: $\underline{5}$}

\footnotetext{
${ }^{4}$ For a fuller discussion of the high-income taxpayer dataset, see Nakazato, Ramseyer \& Rasmusen (2009, 2010, 2011) and Ramseyer (2009).

${ }^{5}$ For a discussion of the relative merits of controlling or not controlling for education in measuring changes in social capital, see Putnam (2000, 418-19).
} 
I include four proxies for the level of education within a community:

Advance to high school: The percentage of middle school (grades 7-9) students in 2002 who advanced to high school (grades 10-12). Education in Japan is compulsory only through grade 9. I take the data from Toba $(2005,89)$.

Advance to university: The percentage of high school students in 2002 who advanced to university. I take the data from Toba $(2005,90)$.

Expenses per student, elementary school: The mean amount spent on each elementary school student in 2008, in 1,000 yen. I take the data from Monbu (2008).

Expenses per student, high school: The mean amount spent on each high school student in 2008, in 1,000 yen. I take the data from Monbu (2008).

F. Independent Variables -- Social Capital:

1. Introduction. -- Scholars have yet to settle on a single best proxy for social capital. Given the vagueness of the idea, it is hard to see how they could. Because the concept remains so nebulous, I take as broad an approach as I can. Putnam (2000, 414; orig. in ital.) describes the challenge nicely:

No single source of data is flawless, but the more numerous and diverse the sources, the less likely that they could all be influenced by the same flaw. Two independent (though necessarily imperfect) strands of evidence are better than one, and more than two are better still, especially if they have different imperfections.

Following this maxim, I choose 13 variables that (loosely to be sure) reflect different aspects of social capital: civic engagement, social engagement, workplace engagement, community infrastructure, family cohesion, and community cohesion. Although the 13 variables cover a wide range of phenomena, they correlate with each other closely (see Table 2). Of the 72 possible pairs among them, the correlation is statistically significant at the 10 percent level in 49. Apparently, most of the variables capture the same basic pattern of the inter-prefectural variation.

[Insert Table 2 about here.]

2. Civic engagement. -- I begin with voter turnout rates and newspaper subscriptions. The former represents the most straightforward measure of civic engagement: how many people participate in elections? The latter measures how hard people try to learn what they need to know to vote intelligently. Thus Putnam (2000, 36), for example, calls newspaper readership a measure of popular "interest in politics and current events."

Voter turnout: Voter turnout rates for the national election in 2003. I take the data from Somu (2003).

Newspaper readership: The percent of households subscribing to the morning edition of the Asahi newspaper from July to December, 2011. The Asahi is the closest thing Japan has to a "newspaper of record." With a diffusion rate of 11 percent of the households, it undersells the Yomiuri (15 percent) but the latter lacks the Asahi's "gravitas." The diffusion rate of the 
Mainichi is 6 percent. The correlation coefficients among the three papers range from .62 to .80; all are significant at better than 0.1 percent. I take the data from Nihon ABC (2011).

3. Social engagement. -- To capture the extent to which people participate in their community, I examine volunteering rates and religious affiliation. The former captures their willingness to help keep their community intact. The latter reflects a subsidiary facet of the same willingness. According to Putnam (2000,67), religious participation functions "as a powerful correlate of most forms of civic engagement"; according to Murray (2012, 207), it constitutes "one of the key sources of social capital in a community."

Volunteering: Percentage of residents 15 years or older performing volunteer work, 2006. I take the data from Somu (2006).

Religious followers, PC: The number of members of a religious organization (of any faith) in 2008, per capita. I take the data from Bunka cho (2008).

4. Workplace engagement. -- "Many people form rewarding friendships at work," writes Putnam (2000, 87-88), and "feel a sense of community among co-workers, and enjoy norms of mutual help and reciprocity on the job." As a result, those with low job tenure enjoy less "trust and social connectedness in the workplace." And those who lose work completely withdraw psychologically from the community itself. The financial stress from their unemployment places "a profoundly depressing effect on social involvement" (Putnam, 2000, 192-193), and leads to "less time spent with friends, ... less frequent attendance at church, less volunteering, and less interest in politics." (2009).

Job tenure: Average number of years on a job, 2009. I take the data from Gekkyu

Unemployment rate: Unemployment rate in 2010. I take the data from Somu (2012).

5. Community infrastructure. -- Through their government, citizens can invest in the facilities and staff necessary to keep their community cohesive. They can hire people to run community centers, and they can hire police officers to keep order. About the police, Putnam (2000, 308) writes:

Higher levels of social capital, all else being equal, translate into lower levels of crime. ... States with more social capital have proportionately fewer murders. ... This inverse relationship is astonishingly strong -- as close to perfect as one might find between any two social phenomena.

I examine staffing patterns at community centers, and rates of serious crime.

Community center staff, PC: The number of staff at local community centers (kominkan) in 2005, per capita. I take the data from Monbu (2005).

Crime rate: The number of violations of the Criminal Code (excluding traffic violations) in 2010, per 1,000 population. I take the data from Homu sho (2011). 
6. Family cohesion. -- For measures of family cohesion, I turn to illegitimacy and abortion rates. Bronislaw Malinowski $(1930,137)$ called his "principle of legitimacy" a universal sociological law. All societies insist, he controversially explained, that:

no child should be brought into the world without a man -- and one man at that -assuming the role of sociological father, that is, guardian and protector, the male link between the child and the rest of the community.

Within the modern U.S., children born out of marriages (born "illegitimate") do not fare well. As Murray $(2012,164)$ put it, their mothers "come disproportionately from the lower socioeconomic classes and they tend to provide worse environments for raising children than married mothers." What is more, if mothers are bearing their children outside of marriage, then families are necessarily playing a smaller role in the community -- yet "families with children are the core" of well-functioning communities (Murray, 2012, 165). If illegitimacy is high, social capital is low.

Abortions represent a costly way to limit family size. For the most part, men and women in cohesive families use other ways to prevent pregnancies. If abortions are up, social capital may be down (though I recognize the possibly controversial nature of this claim).

Illegitimacy rates: Percentage of children born outside of marriage, 2010. I calculate the rate from data available at Kosei (2010a).

Abortions PC: Abortions in 2007, per capita. I calculate the rate from data available at Kosei (2008).

7. Community cohesion. -- As measures of community cohesion, take the growth rate of a community and the job prospects of its educated youth. Cohesive communities grow. Their residents thrive. They attract others, and retain young people who might otherwise emigrate. A community's growth rate will thus reflect its relative attractiveness. What is more, because educated men and women contribute disproportionately to a community's stock of social capital, the job prospects for the best-educated youth matter heavily for a community's ability to cohere as an integrated unit. Should those job prospects fall, educated men and women will simply leave.

Population change: Fractional increase in population, 2000 to 2010. I take the population numbers from the Kosei (2010a).

Unemployment, college graduates: Unemployment rate among new college graduates, 2002. I take the data from Toba $(2005,75)$.

8. Other. -- Putnam $(2000,206)$ suggests that "[l]iving in a major metropolitan agglomeration somehow weakens civil engagement and social capital." Hence:

Metropolitan: 1 if the prefecture has one of the 9 most populous cities in Japan; 0 otherwise.

G. Independent Variable -- Attorneys: 
The extent to which couples litigate their divorces might potentially turn on their access to professionals who could handle their claims. Accordingly, any attempt to explain litigation rates should account for the availability of attorneys. Because their number is endogenous to the use of litigation, however, ordinary least squares is inappropriate.

In their exploration of Japanese prefectural litigation rates, Tom Ginsburg \& Glenn Hoetker (2006) instrument the number of attorneys by the population of a distinct group of nonlawyer legal professionals (judicial scriveners) and the high court in whose jurisdiction the prefecture falls. They explain:

We use the high court district for each prefecture (a set of seven dummy variables) and the number of shiho shoshi (legal Scriveners) in the prefecture as identifying variables. While attorneys and judges may have preferences regarding the high court district in which they want to practice, we expect that few potential litigants will be aware of what high court district they are in, much less be aware of the implications of those districts for litigation they might pursue. Shiho shoshi should not affect the amount of litigation, as litigation is limited to bengoshi [attorneys]. However, since the services of shiho shoshi and bengoshi overlap somewhat (for example, legal advice), the presence of shiho shoshi would influence the economic attractiveness of a prefecture to an attorney.

In this article, I take same approach.

Attorneys PC: The number of attorneys per capita, 2010. I take the data from Nihon bengoshi (2011, 84-85).

Scriveners PC: The number of judicial scriveners per capita, 2012. I take the data from Nihon shiho (2012).

III. Japanese Divorce Litigation -- the Results:

A. Introduction -- The Contrast:

1. Economics and education. -- As homogeneous as Japan may seem to the casual tourist, the country incorporates substantial contrasts -- in wealth, in education, and in social capital. And few pairs exhibit as massive a contrast as Okinawa and Tokyo. Okinawa epitomizes the periphery; Tokyo represents the center. Okinawa lies at the southern tip of Japan; Tokyo sits at the heart of the country. Okinawa was ruled by others; Tokyo ruled others. Okinawa fell under the power of a Japanese clan in in the 17th century, and became a prefecture in the 19th; Tokyo has been the seat of government since 1600 .

Okinawa is poor; Tokyo is rich. Okinawans earn the lowest income per household in Japan: 3.24 million yen (Tab. 3, Pan. A). Tokyo residents earn the highest: 6.00 million. Okinawan households hold the smallest bank accounts in Japan: 5.07 million yen (Tab. 3, Pan. B). Tokyo families hold the biggest: 19.6 million.

[Insert Table 3 about here.]

Okinawa has no jobs; Tokyo recruits. At 7.5 percent, unemployment in Okinawa is the highest in the country (Tab. 3, Pan. C). In Tokyo, unemployment sits at 5.5 percent. If Okinawans do find a job, they do not keep it as long as other Japanese. At 8.7 years, the mean job tenure in Okinawa is the shortest in the country (Tab. 3, Pan. D). In Tokyo, it is 11.1 years.

Okinawans drop out of school; Tokyo offers the best universities in the country. Of all high school graduates, those from Okinawa are least likely to go to college: 30.1 percent (Tab. 3, Pan. E). Of those from Tokyo, 52.4 percent do. When they do finish college, Okinawan 
students find it extraordinarily hard to find jobs. Among its recent graduates, 28.7 percent were unemployed (Tab. 3, Sec. F). Among Tokyo graduates, only 21.5 percent were.

2. Social capital. -- World War II brutalized Okinawa. The U.S. army and marines landed on the islands in April 1945, and fought for two months. About 100,000 Japanese soldiers died, and somewhere between 40,000 and 150,000 Okinawa civilians died too. Apparently, some Japanese army commanders may have shot civilians lest they spy for the Americans. Some may have ordered civilians to commit mass suicide rather than surrender to the Americans.

And Okinawans have never let the rest of Japan forget. The scope of the travesties remains a dispute (Hata, 2009). National bureaucrats and politicians routinely cite low estimates of wartime civilian deaths. Okinawan politicians and commentators insist on high, and use the claims (together with the ostensible continuing insult from the U.S. bases) to demand large subsidies. The transfer payments from the national government are indeed enormous (Hook, 2009, 42-44). Six decades after the end of the war and three after the reversion to Japan, the prefecture remains hugely dependent on the national fisc.

The poverty and low schooling in Okinawa suggest low social capital; the wealth and education in Tokyo suggest high. Consistent with this, Okinawa has the third lowest number of religious followers per capita in Japan (Tab. 3, Pan. G). Metropolitan (and apparently secular) Tokyo has the third highest. Okinawa has .403 divorces for every marriage (Tab. 3, Pan. H). Tokyo has .289, and the lowest rate in the country. Okinawa has the highest rate of shotgun marriages: 42.4 percent (Tab. 3, Pan. I). Tokyo has the lowest: 19.5 percent. ${ }^{6}$ Okinawa has the highest illegitimacy rate in the country: 3.99 percent (Tab. 3, Pan. J). At 1.97 percent, the rate in Tokyo is half that.

\section{B. Litigation and Economic Stakes:}

By the classic model of litigation and settlement, wealthier communities should have higher litigation rates. Other empirical studies -- whether of Japan (Ginsburg \& Hoetker, 2006) or elsewhere (Eisenberg, et al., 2012) -- confirm this logic. In Panel A of Table 4, I regress the settlement rate on three indices of wealth (the regression is OLS, and the data are prefecturelevel). Although the effect is weaker than in some other studies, the regressions confirm the classic model: the coefficient on per capita bank savings is statistically significant at the 10 percent level in the full model. According to the regressions, in other words, couples in wealthier prefectures are less likely to settle their divorces out of court (Tab. 4, Pan. A). Curiously, neither the level of family income nor the number of high-income taxpayers is associated with higher litigation rates.

[Insert Table 4 about here.]

\section{Litigation and Education:}

Again as the classic model predicts, couples in communities with high educational levels are more likely to litigate their divorces. In Panel B of Table 4, I regress the settlement rate on prefecture-level educational variables: the coefficient on the rate at which middle-school students advance to high school is significantly and negatively associated with settlement rates.

\footnotetext{
${ }^{6}$ Shotgun marriages are percent of marriages (earlier of cohabitation or filing of marriage on family registry) that occur less than 9 months before the birth of a child, 2009. See Kosei (2010b).
} 
The better the educational level, the more people litigate their disputes (see Figure 1 for a graphical illustration). Similarly, the more heavily a prefecture invests in elementary school education, the more likely its couples will litigate their divorce.

[Insert Figure 1 about here.]

The other two educational variables do not generate significant results. Neither the rate at which high school graduates advance to university nor the amount that a prefecture invests in high schools is significantly associated with litigation rates.

\section{Litigation and Social Capital:}

1. Introduction. -- Lieberman and Putnam suggest that people in communities with high levels of social capital will more likely settle their disputes than people in low-social-capital communities. If so, then a regression of the settlement rate on proxies for social capital should yield significantly positive coefficients. It does not.

Instead, the data from Japanese divorces suggest that Lieberman and Putnam have the relationship exactly backwards. When statistically significant, the relationship between the proxies for social capital and the settlement rate is an inverse one: the higher the level of social capital in a community, the lower the settlement rate. By implication, the higher the social capital, the higher the rate of litigation.

2. Civic engagement. -- In Panel A of Table 5, I examine measures of civic engagement. I begin with voter turnout rates -- the most direct measure of that civic engagement. Exactly counter to the Lieberman-Putnam logic, turnout rates are negatively associated with settlement rates. The more actively citizens engage in the democratic process, the more likely they will litigate rather than settle their divorces out of court.

[Insert Table 5 about here.]

Note that the wealth of a community and the rate at which its middle school students advance to high school remain negatively associated with settlement rates. This is consistent with the classic model. Newspaper readership is not significantly associated with litigation rates.

3. Social engagement. -- In Panel B, I use measures of social engagement. Again, the association between social capital and settlement rates runs opposite to the Lieberman-Putnam conjecture. In communities where citizens volunteer for local responsibilities, they sue (i.e., do not settle). Where they participate in local temples and shrines, they sue.

As in Panel A and consistent with the classic model, the high-school advancement rate is negatively and significantly associated with the settlement rate. The coefficient on the level of community savings is also negative, and in one specification almost significant.

4. Workplace engagement. -- In Panel C, I study measures of workplace engagement. Here too, higher levels of social capital are associated with lower settlement rates (higher litigation rates). In prefectures with long job tenure, the settlement rate is low and -- by implication -- the litigation rate high. In prefectures with low unemployment, the settlement rate is low -- and the litigation rate high. Note that the rate at which students advance to high school again remains significantly negatively associated with the settlement rate.

5. Community infrastructure. -- In Panel D, I employ proxies for the level of community infrastructure. The relationship between these measures of social capital and the settlement rate 
tracks results in the preceding panels. Where people invest heavily in their community centers (their kominkan), couples litigate their divorces. Where police keep crime levels low, couples litigate their divorces. And here, too, the high-school advancement rate and the wealth of the community are negatively associated with settlement rates.

6. Family cohesion. -- In Panel E, I explore measures of family cohesion. Whether couples use abortions to control pregnancies is not correlated to settlement rates. The extent to which they bear children out of marriage, however, is: the greater the illegitimacy rate (the lower the social capital), the higher the settlement rate.

The relationship between illegitimacy and settlement is extremely strong. Later regressions indicate that illegitimacy correlates more significantly with the settlement rate than does any other proxy for social capital (see Figure 2 for a graphical illustration). Scholars like Murray stress the extent to which illegitimacy captures social dysfunction. According to Panel E, that dysfunction correlates positively not with litigation but with out-of-court settlement.

[Insert Figure 2 about here.]

7. Community cohesion. -- Panel F shows two other ties between proxies for social capital and the settlement rate in divorce. First, and consistent with Panel C, unemployment rates among college graduates are positively associated with settlement rates. The harder graduates find it to locate a job, the more people settle divorces out of court.

Second, the more a community has grown (the more it thrives), the more people settle their divorces. Here (only here), the association between social capital and settlement is positive -- consistent with the Lieberman-Putnam conjecture. It is not, however, stable. It appears only in the univariate regression, and disappears when I control for community wealth and education.

8. Urban character. -- Finally, Putnam suggests that urban communities enjoy less social capital than rural. According to Panel G, couples in the most urban prefectures (those with the largest cities) are most likely to settle their disputes. As with the population variable in Panel F, however, the result is unstable. Add community wealth and education, and the effect disappears.

9. Conclusion. -- These results present a puzzle. I know of no reason why higher levels of social capital should be associated with lower levels of out-of-court settlement -- and, by implication, with higher levels of litigation. Most likely, my proxies for wealth and education fail to capture the full extent of the variation along those dimensions. If so, then the proxies for social capital could incorporate some of the effect of wealth and education (with which it is correlated). Given that people in richer and better educated communities litigate their disputes more than people in poorer and less educated communities, perhaps my results represent omitted variable bias: the proxies for social capital capture some of the residual effect of wealth and education.

The more basic point, however, is clear: the data show no sign that social capital increases out-of-court settlement. Commentators suggest that people in societies with higher levels of social capital more readily resolve their disputes out of court. In the context of Japanese divorces, the data show no evidence of any such effect.

\section{E. Alternative Measures of Settlement}


1. The dependent variables. -- In Table 6, I consider several alternative measures of outof-court divorce settlements. In Column (A), I reproduce the variable used in Tables 4 and 5:

(A) Divorces by agreement (kyogi)/total divorces, both from Kosei (2011)

Kosei (2011) details two other types of settlements that the divorcing couple might reach. Column (B) adds these others to the numerator:

(B) Divorces by agreement (kyogi), conciliation (chotei), or in-court settlement (wakai)/total divorces, all from Kosei(2011)

Rather than rely on the number of negotiated divorces in Kosei (2011), in Column (C) I take the total number of divorces and subtract from it the number of divorce petitions filed in court. I take the latter from court records (Saiko, 2011):

(C) [Total divorces (as given in Kosei, 2011) less divorce filings in court (as given in Saiko, 2011)]/total divorces (as given in Kosei, 2011)

(A), (B), and (C) each approximates the "settlement rate." In Column (D) I measure expressly the "litigation rate": I divide the number of divorce cases litigated in court (from court records; Saiko, 2011) by total divorces. Note that the coefficients in Column (D) should bear the opposite sign from those in the first three columns:

(D) Litigated divorce cases (hanketsu, as given in Saiko, 2011)/total divorces (as given in Kosei, 2011)

The harshest divorce battles usually involve fights over children. In Column (E), I divide the number of custody petitions by the total number of divorces:

(E) Custody petitions (as given in Saiko, 2011)/total divorces (as given in Kosei, 2011)

[Insert Table 6 about here.]

2. Results. -- The regressions generate very similar results. In turn, that uniformity suggests that the outcomes above are not an artifact of the way I define settlement. Consider several observations about the first four regressions (the results for variable (E) are not significant).

First, in each regression in Panel I litigation is positively associated with community wealth. Per capita savings are negatively correlated with settlement (A, B, and C), and positively with litigation (D). In Panel II the significance levels fall, but the direction of the effect remains the same.

Second, in each regression in Panel I litigation is positively associated with educational levels. The rate by which students advance to high school is negatively correlated with settlement (A, B, and C), and positively with litigation (D). In Panel II the significance levels again fall, but the direction of the effect remains the same.

Third, in one regression (C) volunteer work is associated with lower settlement rates.

Last, the illegitimacy rate produces a very strong effect. Consistently, high rates of illegitimacy are positively associated with settlement rates (A, B, and C), and negatively with litigation (D).

\section{F. The Effect of Attorneys:}

Studies of litigation rates often find that the rates turn on the accessibility of a lawyer. Ginsburg \& Hoetker (2006), for example, reach exactly that conclusion with prefecture-level data much like what I use for this study. Accordingly, in Table 7 I include the number of lawyers per capita in each prefecture. Because that number is endogenous to the amount of litigation, I instrument it by the Ginsburg-Hoetker approach (see Sec. II.G.). 
[Insert Table 7 about here.]

The number of lawyers has no effect on the litigation rate. Instead, the coefficient on Attorneys PC is consistently insignificant. Figure 3 illustrates graphically why one would not expect a significant coefficient. In the figure, I plot the settlement rate against Attorneys PC. The correlation coefficient between the two variables is .26, and is significant at the 8 percent level. Note, however, that the direction is wrong: the greater the concentration of attorneys, the less litigation. That significance is entirely a function of the two prefectures with the highest lawyer concentration: Tokyo and Osaka. Drop the two prefectures, and the correlation coefficient turns insignificant.

[Insert Figure 3 about here.]

Other aspects of Table 7 track the earlier regressions. First, the coefficient on Savings PC is significantly negative in 3 specifications: the richer the prefecture, the more litigation (i.e., the less settlement). The coefficient on Advance to High School is significantly negative in all 7 specifications: the better educated the prefecture, the more litigation. Voter turnout and Volunteering are both significantly negatively associated with settlement: the higher the level of civic and social engagement, the more litigation. Finally, illegitimacy rates are strongly positively associated with settlement: the more intact the families (the lower the illegitimacy rate), the more litigation.

\section{Determinants of Divorce:}

A. Introduction:

Turn to the question of the ties between social capital and the decision to divorce. In the analysis above, I take the decision to divorce as given, and ask whether the level of social capital in a community is correlated with an ability to negotiate that divorce privately. I find no evidence of such an association. Turn now to the divorce itself. Ask, in other words, whether the level of social capital in a community is correlated with the decision about whether to divorce at all: are couples in some communities more likely to divorce than couples elsewhere?

\section{B. The Classic Model:}

Begin with Gary Becker's classic discussion of marriage and divorce (1991, Ch. 10). Becker posits that couples will stay married if but only if their combined welfare is higher married than divorced (id., 331). If they enjoy a higher aggregate welfare within marriage, they will stay married. If they would have greater total welfare outside of marriage, they will divorce.

Whether a couple earns higher welfare in marriage will turn in part on the investments they make in the relationship (id., 329). Suppose they invest heavily in skills, qualities, assets (think children) that pay higher returns if their marriage endures. They will more likely find their combined welfare higher in marriage, and avoid divorce. In turn, they will make higher levels of those marriage-specific investments if they each think their partner will not explore their "outside" options.

Social capital can provide the "glue" necessary to prevent a spouse from exploring those alternative arrangements. If he (or she, the logic runs in both directions) probably will not demand a divorce, she can safely invest in marriage-specific skills and assets. If she makes those marriage-specific investments, they will both earn returns from their marriage that they would lose if they divorced. And if they earn returns in marriage that they would forfeit under divorce, they will less likely divorce. 
Consider how social capital might give that "glue." In communities with high levels of social capital, couples may have large networks of mutual friends that would unravel in a divorce. They may find fulfillment in a religious institution that discourages (or perhaps bans) divorce. If the institution also bans remarriage, it slashes their divorced welfare even further. More broadly, the couple may live within deep and broad-ranging networks of friendships, family ties, and other social relations. If these networks discourage divorce (as many networks in high-socialcapital communities do), each spouse will be less likely to explore his (or her) divorced alternatives. If one spouse does not explore those alternatives, then the other spouse can more safely invest in their marriage. And if they each invest in marriage-specific skills and assets, they will together generate the returns necessary to keep their combined welfare higher within marriage than without. ${ }^{7}$

\section{Empirical Evidence:}

In Table 8, I regress the divorce rate on the independent variables discussed above. More particularly, as the dependent variable I take the number of divorces in a prefecture (2010, from Kosei, 2010a), and divide it by the number of marriages (Kosei, 2010a). As the model predicts, at least some proxies for social capital do correlate with a lower divorce rate.

[Insert Table 8 about here.]

First, wealthier communities enjoy more stable marriages. Becker (1991, 336-37) and Murray $(2012,156)$ find the same phenomenon in the U.S. Given that richer communities have higher levels of social capital, the result is consistent with Beckerian theory. ${ }^{8}$ Figure 4 illustrates the result graphically. The coefficients on education are significant in only two specifications, however, and the two run in opposite directions.

[Insert Figure 4 about here.]

Second, higher illegitimacy rates are associated with higher divorce rates. Illegitimacy is high where social capital is low, and where social capital is low divorce rates are high. Note Figure 5 -- a graphical illustration of the phenomenon.

[Insert Figure 5 about here.]

Third, higher growth rates in a prefecture are associated with lower divorce rates. Prefectures grow when the communities thrive -- when the economy provides good jobs, and the cities provide vibrant communities within which to live and raise families. Again, where social capital is high, divorce rates are low.

\section{Divorce and Traffic Accidents Compared:}

A. The Question:

Disputes over divorces are peculiar in a variety of ways, of course. The results might generalize, but logically need not. Consider the dichotomies: A divorce is a quarrel between two people who know each other very well. Contract disputes take place between people who often do not know each other well, and tort disputes frequently involve complete strangers. Divorces involve the family, the central unit in a community. Contract and tort disputes can

${ }^{7}$ As Becker (1991, 329) notes: "Expectations about divorce are partly self-fulfilling because a higher expected probability of divorce reduces investments in specific capital and thereby raises the actual probability."

${ }^{8}$ In other words, the significant coefficient on Savings PC is at least in part the result of omitted variable bias created by the inadequacy of my proxies for social capital. Consistent with this explanation, note that the result on Savings PC is insignificant when the regression includes the Illegitimacy rate. As noted earlier, the Illegitimacy rate seems to capture social capital most strongly of all of the independent variables. 
involve people from cities far distant. Divorces often involve children. Many torts and contracts involve no children at all. All these factors could affect how social capital shapes -- or does not shape -- the way people resolve their various disputes.

Take traffic accidents. These accidents are common, and form a substantial part of the docket of all modern wealthy societies. In Japan as elsewhere, most traffic victims negotiate compensation from the driver's insurer out of court -- but some do sue (Ramseyer, 1989). Through the mid-1990s, Japanese court statistics disclosed the number of cases they filed at the prefectural level. Because the statistics no longer give these data, I take the number of trafficaccident damage claims filed in either district court or summary court in 1994 (Saiko, 1994, tabs. 10, 23).

The question at stake is whether social capital affects the ability of people to resolve their disputes out of court. Accordingly, much like the way I divided the number of settled divorces by total divorces, in Table 9 I divide the number of 1994 traffic suits by the number of 1993 traffic deaths (Keisatsu, 1994, tab. 7-3). Many traffic suits did not involve wrongful death, of course. I use deaths as a denominator to proxy for the quantity of major traffic disputes. I then regress this fraction on the independent variables used above. ${ }^{9}$ Because the number of attorneys is endogenous to the litigation level, I again instrument it according to the Ginsburg-Hoetker procedure (see Sec. II.G.).

[Insert Table 9 about here.]

\section{B. The Results:}

The results differ fundamentally from those over divorces. In the divorce data, the availability of an attorney made no difference. Instead, the settlement rate turned on wealth and education. The rate also turned on social capital, but in a way opposite to that of most discussions -- suggesting that it reflected an omitted variable bias.

Among traffic accidents, the litigation rate turns almost exclusively on the availability of an attorney. In each specification in Table 9, the coefficient on the per capita number of attorneys is positive and significant: the greater the concentration of attorneys, the more likely victims of traffic accidents will file suit rather than negotiate their settlements out of court. Indeed, with a t-statistic ranging from 4.40 to 7.80 , the coefficient is massively significant.

This is not to say that litigation is uncorrelated to community income. It is indeed correlated. As Table 10 shows, litigation rates are significantly correlated with incomes and unemployment rates, and somewhat correlated to savings. That significance disappears in the Table 9 regressions because attorneys settle so heavily in the wealthier communities.

[Insert Table 10 about here.]

The Table 9 regressions generate only insignificant coefficients on most of the independent variables besides Attorneys PC. The coefficient on Illegitimacy is significant at the 10 percent level: accident victims in prefectures with high illegitimacy rates are more likely to sue (exactly as Lieberman and Putnam predict). The coefficient on Metropolitan is also significant and positive: accident victims in urban prefectures are more likely to sue (again, as Putnam predicts). All other proxies for social capital are insignificant.

The contrast between divorce and traffic disputes probably turns on the extent to which people handle their quarrels pro se. In divorce, the availability of an attorney has no relation to

\footnotetext{
${ }^{9}$ Because of the earlier years used for the dependent variable, I take incomes for 1996, vounteering in 1991, unemployment in 1990, crimes in 1995, attorneys in 1997, and the change in population over 1995-2010.
} 
whether couples file suit -- recall the Figure 3 scatter diagram. Compare this figure with the comparable diagram for traffic accident litigation in Figure 6. Probably, most people handle their divorces themselves whether they have access to an attorney or no.

[Insert Figure 6 about here.]

As Figure 6 shows, in traffic cases the numbers of suits and lawyers are strongly and positively correlated. In communities with high lawyer concentrations, many people probably retain a lawyer after a major traffic accident. The correlation coefficient between suits and lawyers is .86, significant at more than the 0.1 percent level. Tokyo and Osaka have the highest concentration of attorneys, of course. Drop those two and the correlation coefficient falls, but only to .64 and remains significant at more than the 0.1 percent level.

The contrast between the divorce and traffic results suggests a simple moral: people handle different kinds of disputes differently. Whether they live in a community with many lawyers has no bearing on whether they sue or settle their divorces. Whether they live in a wealthy or educated community does. Whether they live in a community with many lawyers does affect whether they sue or settle their claim over a traffic accident. Indeed, it matters more than anything else. Whether people live in a community with high levels of social capital does not matter for divorce litigation. To at least a modest degree, it apparently does matter for traffic disputes: in urban prefectures and those with high illegitimacy rates, traffic victims seem more likely to sue.

\section{Conclusions}

Scholars commonly define a "litigation rate" as the number of suits per capita. In doing so, they implicitly conflate two questions: (A) how common are the disputes, and (B) how often do people litigate those disputes? In this article, I use data on Japanese divorces and traffic accidents to disentangle these questions. The frequency with which couples divorce and the number of fatal traffic accidents provide evidence on question (A); whether the parties involved litigate the divorce or accident gives evidence on question (B).

I find that couples in poorer communities are more likely to divorce. I find some evidence that those in communities with low levels of social capital are more likely to divorce. Conditional on the decision to divorce, I find that couples in wealthier communities are more likely to litigate the terms of the divorce. I find that couples in better-educated communities are more likely to litigate the divorce. But wealth and education held constant, I find no evidence that couples in communities with high levels of social capital are more likely to settle their disputes, and no evidence that the accessibility of attorneys matters.

The data on traffic accidents suggest that these conclusions do not necessarily generalize. In disputes over serious accidents, the accessibility of an attorney matters crucially: the more attorneys per capita, the higher the litigation rate. Although community wealth is correlated with litigation rates, attorneys tend to congregate in richer communities -- and with the number of attorneys held constant; wealth is no longer associated with higher litigation levels. Some evidence suggests, however, that for disputes over traffic accidents, people in communities with higher levels of social capital may be more likely to settle their dispute out of court. 
Table 1:

Selected Summary Statistics

\begin{tabular}{|c|c|c|c|c|}
\hline & Min & Median & Mean & $\operatorname{Max}$ \\
\hline \multicolumn{5}{|l|}{ Dependent variable: } \\
\hline Settlement rate & .804 & .871 & .869 & .921 \\
\hline \multicolumn{5}{|l|}{ Economic variables: } \\
\hline Income PC $(x 1 \odot, \odot \odot \odot)$ & 325 & 436 & 437 & 600 \\
\hline Savings PC $(x 1,000)$ & 5,068 & 15,647 & 14,887 & 19,577 \\
\hline High income TP $(x 1,000)$ & .149 & .330 & .406 & 1.881 \\
\hline \multicolumn{5}{|l|}{ Education variables: } \\
\hline Advance to high sch & 92.8 & 96.7 & 96.5 & 98.4 \\
\hline Advance to univ & 30.1 & 43.7 & 43.1 & 53.5 \\
\hline Expenses PC elem ed & 761 & 905 & 924 & 1,211 \\
\hline Expenses PC high sch & 941 & 1,141 & 1,171 & 2,173 \\
\hline \multicolumn{5}{|l|}{ Social capital variables: } \\
\hline Voter turnout & 38.2 & 58.8 & 59.5 & 69.4 \\
\hline Newspaper reader & 0.22 & 9.52 & 11.3 & 25.4 \\
\hline Volunteering & 19.7 & 27.6 & 28.2 & 34.5 \\
\hline Religious followers PC & .625 & 1.485 & 1.720 & 6.473 \\
\hline Job tenure & 8.7 & 11.6 & 11.5 & 13.0 \\
\hline Unemployment & 3.2 & 4.7 & 4.8 & 7.5 \\
\hline Com'ty staff PC $(x 1, \odot \odot \odot)$ & .02 & .11 & .13 & .44 \\
\hline Crime rate & 4.99 & 10.01 & 10.50 & 18.87 \\
\hline Illegitimacy rates & 1.29 & 2.10 & 2.15 & 3.99 \\
\hline Abortions PC $(x 1,000)$ & .293 & 2.07 & 2.04 & 2.89 \\
\hline Population change & -.087 & -.027 & -.018 & .083 \\
\hline Unemployment coll grads & 7.5 & 21.5 & 21.8 & 42.7 \\
\hline Metropolitan & 0 & 0 & 191 & 1 \\
\hline \multicolumn{5}{|l|}{ other: } \\
\hline Attorneys PC $(x 1, \odot \odot \odot)$ & .058 & .094 & .126 & 1.076 \\
\hline Scriveners PC $(x 1,000)$ & .093 & .154 & .154 & .270 \\
\hline
\end{tabular}

Notes: See text for definitions and sources of variables. 


\section{Table 2: \\ Social Capital -- Correlation Coefficients}

\begin{tabular}{|c|c|c|c|c|c|c|c|}
\hline I & Voter T0 & News & Voluntr & Rel Fln & Tenure & \multicolumn{2}{|c|}{ Unemplymt Comm'ty } \\
\hline Voter turnout| & 1.0000 & & & & & & \\
\hline Newspapr rdsp & $\begin{array}{r}-0.0845 \\
\odot .5857\end{array}$ & 1.0000 & & & & & \\
\hline Volunteering & $\begin{array}{l}0.6472 \\
0.00 \odot \odot\end{array}$ & $\begin{array}{r}-\odot .2591 \\
\odot .0895\end{array}$ & 1.0000 & & & & \\
\hline Religious fw & $\begin{array}{l}0.2707 \\
\odot .0657\end{array}$ & $\begin{array}{l}0.0572 \\
\odot .7124\end{array}$ & $\begin{array}{l}0.2392 \\
0.1053\end{array}$ & $1.000 \odot$ & & & \\
\hline Job tenure & $\begin{array}{l}0.4703 \\
0.0008\end{array}$ & $\begin{array}{l}0.1179 \\
0.4458\end{array}$ & $\begin{array}{l}0.2161 \\
0.1447\end{array}$ & $\begin{array}{l}0.2739 \\
0.0624\end{array}$ & 1.0000 & & \\
\hline Unemployment & $\begin{array}{r}-\odot .5962 \\
\odot .0 \odot \odot \odot\end{array}$ & $\begin{array}{l}0.0330 \\
0.8315\end{array}$ & $\begin{array}{r}-0.5994 \\
0.000 \odot\end{array}$ & $\begin{array}{r}-0.4300 \\
0.0026\end{array}$ & $\begin{array}{r}-0.5531 \\
0.0001\end{array}$ & 1.0000 & \\
\hline Community CS & $\begin{array}{l}\odot .4450 \\
\odot .0017\end{array}$ & $\begin{array}{r}-0.1778 \\
0.2482\end{array}$ & $\begin{array}{l}\odot .6063 \\
\odot .000 \odot\end{array}$ & $\begin{array}{l}\odot .4081 \\
\odot .0 \odot 44\end{array}$ & $\begin{array}{l}\odot .2474 \\
\odot .0936\end{array}$ & $\begin{array}{r}-0.4265 \\
0.0028\end{array}$ & 1.0000 \\
\hline Crime rate & $\begin{array}{r}-0.4334 \\
0.0023\end{array}$ & $\begin{array}{l}0.5231 \\
0.0003\end{array}$ & $\begin{array}{r}-0.5475 \\
0.0001\end{array}$ & $\begin{array}{r}-\odot .1246 \\
\odot .4041\end{array}$ & $\begin{array}{r}-0.0577 \\
0.7001\end{array}$ & $\begin{array}{l}0.2575 \\
0.0805\end{array}$ & $\begin{array}{r}-\odot .4526 \\
\odot .0014\end{array}$ \\
\hline Illegitimacy & $\begin{array}{r}-\odot .4848 \\
\odot .0006\end{array}$ & $\begin{array}{r}-0.1850 \\
0.2293\end{array}$ & $\begin{array}{r}-\odot .3958 \\
\odot .0059\end{array}$ & $\begin{array}{r}-0.3146 \\
0.0313\end{array}$ & $\begin{array}{r}-0.6294 \\
0.00 \odot \odot\end{array}$ & $\begin{array}{l}\odot .6877 \\
\odot .0 \odot \odot \odot\end{array}$ & $\begin{array}{r}-\odot .3188 \\
\odot .0289\end{array}$ \\
\hline Abortions & $\begin{array}{l}0.1511 \\
0.3107\end{array}$ & $\begin{array}{r}-0.4229 \\
0.0042\end{array}$ & $\begin{array}{l}0.2101 \\
0.1563\end{array}$ & $\begin{array}{r}-0.0523 \\
0.7268\end{array}$ & $\begin{array}{l}\odot .0384 \\
\odot .7980\end{array}$ & $\begin{array}{l}0.0133 \\
\odot .9292\end{array}$ & $\begin{array}{l}0.1469 \\
0.3245\end{array}$ \\
\hline Pop change & $\begin{array}{r}-\odot .4736 \\
\odot .0008\end{array}$ & $\begin{array}{l}\odot .3738 \\
\odot .0124\end{array}$ & $\begin{array}{r}-0.3721 \\
0.0100\end{array}$ & $\begin{array}{r}-\odot .0978 \\
\odot .5133\end{array}$ & $\begin{array}{r}-0.3245 \\
0.0260\end{array}$ & $\begin{array}{l}\odot .2362 \\
\odot .1100\end{array}$ & $\begin{array}{r}-0.3660 \\
0.0114\end{array}$ \\
\hline Col grad unem| & $\begin{array}{r}-0.4485 \\
0.0016\end{array}$ & $\begin{array}{l}\odot .1327 \\
\odot .3906\end{array}$ & $\begin{array}{r}-0.3971 \\
0.0057\end{array}$ & $\begin{array}{r}-0.1240 \\
0.4061\end{array}$ & $\begin{array}{r}-0.6705 \\
0.000 \odot\end{array}$ & $\begin{array}{l}\odot .5468 \\
0.0001\end{array}$ & $\begin{array}{r}-0.3431 \\
0.0182\end{array}$ \\
\hline Metropolitan & $\begin{array}{r}-0.2781 \\
0.0584\end{array}$ & $\begin{array}{l}0.3735 \\
0.0125\end{array}$ & $\begin{array}{r}-0.5309 \\
0.0001\end{array}$ & $\begin{array}{r}-0.0661 \\
0.6591\end{array}$ & $\begin{array}{r}-0.1894 \\
0.2024\end{array}$ & $\begin{array}{l}0.3820 \\
0.0081\end{array}$ & $\begin{array}{r}-0.4641 \\
\odot .0010\end{array}$ \\
\hline
\end{tabular}


Table 2

Social Capital (Cont'd)

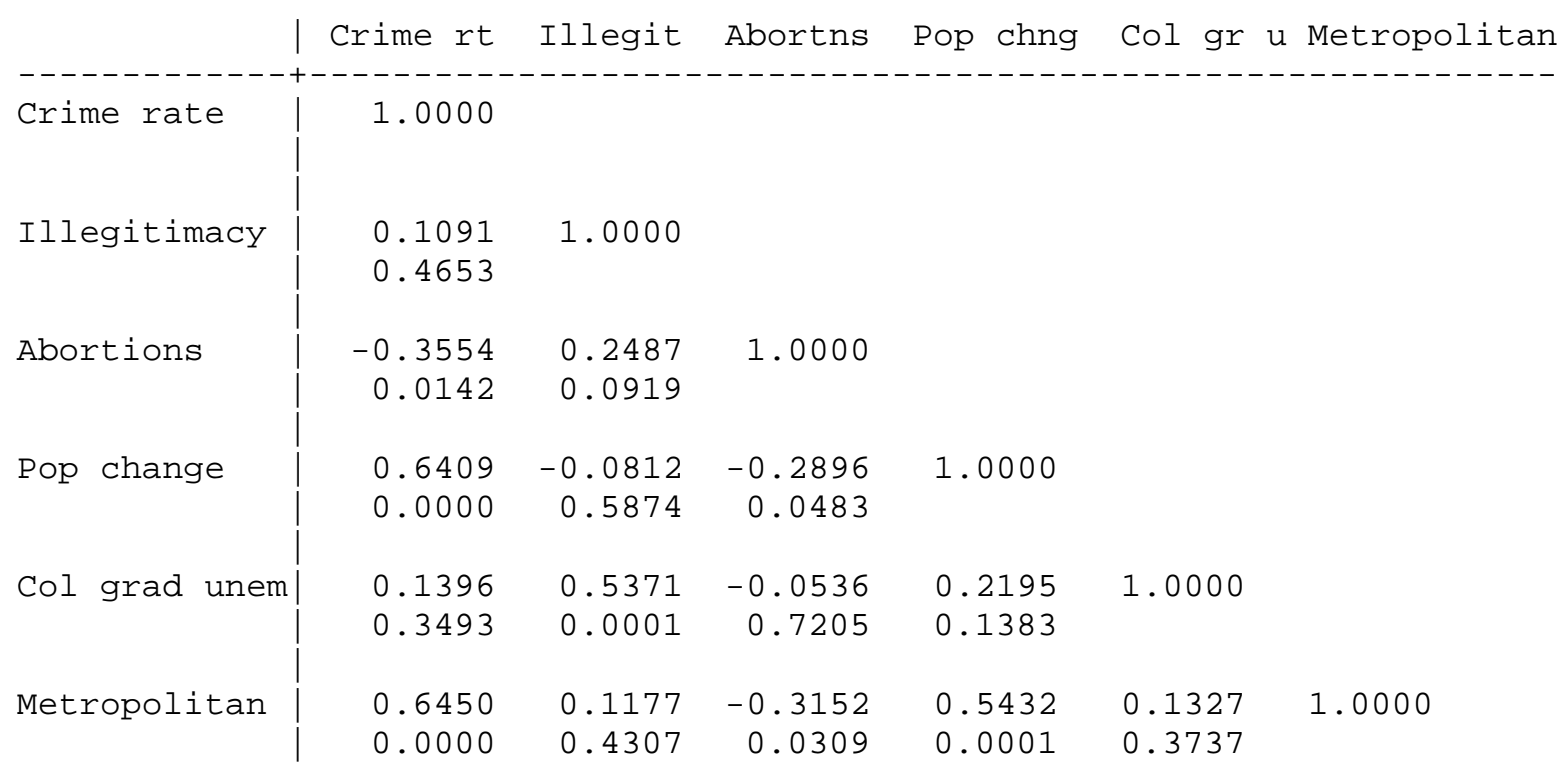

Note: Correlation coefficients, followed by the probability values on the line below. See text for definitions and sources of variables. 


\section{Table 3: High and Low Prefectures}

A. Income

$\begin{array}{ll}\text { Okinawa } & 324 \\ \text { Aomori } & 352 \\ \text { Akita } & 359 \\ \text { Iwate } & 361 \\ \text { Miyazaki (K) } & 363\end{array}$

B. Savings

Lowest five prefectures:

Okinawa $\quad 5,068$

Miyazaki (K) 9,906

Kagoshima (K) 10,204

Aomori

10,904

Nagasaki (K) 10,954
Highest five prefectures:

Ibaragi $\quad 507$

Osaka (M) 524

Aichi (M) 533

Kanagawa (M) 554

Tokyo (M) 600

C. Unemployment (general)

Highest five prefectures:

Okinawa $\quad 7.5 \%$

Osaka (M) $\quad 6.9$

Aomori 6.3

Fukuoka (K, M) 6.0

MIyagi $\quad 5.8$

Highest five prefectures:

$\begin{array}{ll}\text { Aichi (M) } & 19,023 \\ \text { Nara } & 19,091 \\ \text { Fukui } & 19,111 \\ \text { Mie } & 19,394 \\ \text { Tokyo (M) } & 19,577\end{array}$

Lowest five prefectures:

Yamaguchi $\quad 3.9$

Toyama $\quad 3.8$

Gifu $\quad 3.7$

Fukui $\quad 3.3$

Shimane $\quad 3.2$

Tokyo is 5.5

D. Job tenure:

Shortest five prefectures:

Okinawa $\quad 8.7 \mathrm{yr}$

Kagoshima (K) 10.2

Fukuoka (K) 10.4

Miyazaki (K) 10.5

Hokkaido $\quad 10.7$

Longest five prefectures

Yamagata $\quad 12.3 \mathrm{yr}$

Tokushima $\quad 12.4$

Mie $\quad 12.4$

Toyama $\quad 12.7$

Niigata $\quad 13.0$

Tokyo is 11.1

E. University advancement rates

Lowest five prefectures: Highest five prefectures:

Okinawa

Iwate

Aomori

Fukushima

Hokkaido
$30.1 \%$

32.0

32.9

34.2

34.7
Hiroshima

Nara

Tokyo (M)

Hyogo (M)

Kyoto (M)
$51.9 \%$

52.2

52.4

52.5

53.5 


\section{Table 3: \\ High and Low Prefectures (Continued)}

F. Unemployment (recent college graduates):

\begin{tabular}{cccc}
\hline Highest five prefectures: & Lowest five & prefectures: \\
Fukuoka (K, M) & $42.7 \%$ & Gifu & $15.1 \%$ \\
Nara & 30.1 & Nagano & 11.8 \\
Oita (K) & 29.5 & Toyama & 11.5 \\
Kumamoto (K) & 29.4 & Iwate & 9.4 \\
Okinawa & 28.7 & Fukui & 7.5 \\
& & Tokyo is 21.5
\end{tabular}

G. Members of religious organizations (per capita):

Fewest five prefectures Most five prefectures

$\begin{array}{llll}\text { Saitama (M) } & .625 & \text { Hyogo (M) } & 2.609 \\ \text { Chiba } & .654 & \text { Nagano } & 2.809 \\ \text { Okinawa } & .668 & \text { Tokyo (M) } & 3.605 \\ \text { Miyazaki (K) } & .879 & \text { Kagawa } & 5.556 \\ \text { Kochi } & .919 & \text { Shimane } & 6.473\end{array}$

H. Divorce to marriage ratio:

Highest five prefectures:

Aomori $\quad .452$

Hokkaido (M) $\quad .444$

Kochi $\quad .440$

Wakayama $\quad .435$

Akita $\quad .419$

Okinawa is . 403

Lowest five prefectures

Toyama $\quad .318$

Aichi (M) .316

Niigata $\quad .312$

Ishikawa .312

Tokyo (M) .289

I. Shotgun marriages:

\begin{tabular}{|c|c|c|c|}
\hline \multicolumn{2}{|c|}{ Highest five prefectures: } & \multicolumn{2}{|c|}{ Lowest five prefectures: } \\
\hline Okinawa & $42.4 \%$ & Shiga & $21.7 \%$ \\
\hline Saga (K) & 37.5 & Kyoto (M) & 21.6 \\
\hline Fukushima & 36.7 & Aichi (M) & 21.8 \\
\hline Aomori & 36.2 & Kanagawa (M) & 19.5 \\
\hline Kumamoto (K) & 36.0 & Tokyo (M) & 19.5 \\
\hline
\end{tabular}

J. Illegitimacy rate:

Highest five prefectures:

Okinawa

$3.99 \%$

Kochi

3.53

Aomori

3.03

Hokkaido (M) 2.99

Osaka (M) 2.99

$\begin{array}{cr}\text { Lowest five prefectures: } \\ \text { Ishikawa } & 1.48 \\ \text { Gifu } & 1.43 \\ \text { Shiga } & 1.43 \\ \text { Niigata } & 1.31 \\ \text { Toyama } & 1.29 \\ \text { Tokyo is } & 1.97\end{array}$

Continued on next page 


\section{Table 3}

High and Low Prefectures (Continued)

Notes: Variables are as defined in text.

$\bar{M}$ designates a prefecture with one the 10 largest cities.

$\mathrm{K}$ designates a prefecture in the southern island of Kyushu. See text for definitions and sources of variables. 
Table 4:

Economic and Educational Correlates

A. Economic:

Dependent Variable: Settlement Rate

Savings PC

.946

Income PC

$(0.95)$

High-Income TPS PC

.41

$(0.78)$

$-.0 \odot$

.03
$-2.58^{*}$

$(1.93)$

.777

$(0.85)$

17.79

$(1.10)$

17.656

$(1.54)$

.07

B. Educational:

Dependent Variable: Settlement Rate Adv to High Sch

Adv to University

$(3.79)$

Exp per Stud Elem Educ

$(0.11)$ $-87.54^{\star \star *}$ $(3.16)$ $-3.626$ $(0.85)$

Exp per Stud High School $-.498$ $-.255$ $(0.83)$ $(1.84)^{*}$ .158 $.041)$ (1.010

Adj R2 .23 $-.02$ .05 $-.02$ .21

Notes: Coefficients, followed by the absolute value of the t-statistic. All regressions include a constant term. Coefficients on Savings are $x 1000,000 . n=47$. See text for definitions and sources of variables. 
Table 5:

Social Capital Correlates

A. Civic Engagement

Dependent Variable: Settlement Rate

Savings PC

Adv to High Sch

Voter Turnout

$-.002 * * *$

$(4.26)$

$-.809$

$(0.97)$

$-2.21^{* *}$

$(2.38)$

$-.007 * * *$

$-.009 * * *$

$(2.98)$

(3.91)

Newspaper Readership

$(2.98)$

$-.0004$

$(0.08)$

.0002

$(0.48)$

Adj R2

.27

$-.02$

.37

.28

B. Social Engagement:

Dependent Variable: Settlement Rate

Savings PC

Settlement Rate

Adv to High Sch

Volunteering

$-.002 * * *$

(3.50)

Religious Follwr, PC

$-.005 *$

$(1.83)$

$-1.25$

$-1.35$

$(1.32)$

(1.64)

$-.009 * * *$

$-.007^{*}$

$(3.69)$

-.002 **

(2.51)

.05

.34

$-.002$

$(0.60)$

Adj R2

.20

.25

C. Workplace Engagement:

Dependent Variable: Settlement Rate

Savings PC

Adv to High Sch

Job Tenure

$-.017^{* * *}$

(5.13)

.962

(1.07)

$-.006 * * *$

$-.124$

(3.01)

$(0.12)$

$-.017 * * *$

(3.18)

Unemployment Rate

$.010 * * *$

$(4.57)$

(3.17)

$(2.02)$

Adj R2

.36

.16

.49

.31 
Table 5:

Social Capital Correlates (Cont'd)

D. Community Infrastructure:

Dependent Variable: Settlement Rate

Savings PC

Adv to High Sch

Comm'ty Ctr Staff, PC

$-99.179 * * *$

$(3.08)$

Crime Rate

$0 \odot 2$ * *

$(2.55)$

$-1.35$

(1.60)

$-.008^{* * *}$

(3.21)

$-62.080^{*}$

$(1.98)$

.11

.31

.28

E. Family Cohesion:

Dependent Variable: Settlement Rate Savings PC

Adv to High Sch

Illegitimacy rates

$.023^{* * *}$

(5.97)

1.04

(1.25)

$-.006 * * *$

$-1.51$

(2.75)

$.023^{* * *}$

$(5.31)$

Abortions, PC

$-.713$

$(0.11)$

$-.882$

$(0.15)$

Adj R2

.43

$-.02$

.54

.24

F. Community Cohesion:

Dependent Variable: Settlement Rate

Savings PC

Adv to High Sch

Population Growth

$.157^{*}$ *

$(2.17)$

Unemploy't, Coll Grad

$.001 * * *$

(3.11)

$\begin{array}{ll}-1.66^{*} & -.431 \\ (1.86) & (0.44) \\ -.009^{* * *} & -.008^{* * *} \\ (3.17) & (3.39) \\ .072 & \\ (0.91) & .001^{* *} \\ & (2.08) \\ .25 & .31\end{array}$

Adj R2

.07

.16

(Continued on next page) 
Table 5:

Social Capital Correlates (Cont'd)

G. other:

Dependent Variable: Settlement Rate

Savings PC

Adv to High Sch

$(1.82)$

$-.009 * * *$

Metropolitan

$.015^{*}$ *

(2.07)

$(3.40)$

.008

$(1.11)$

Adj R2

.07

.26

Notes: Coefficients, followed by the absolute value of the t-statistic. All regressions include a constant term.

Coefficients on Savings are $x 1000,000 . n=47$. See text for definitions and sources of variables. 


\section{Table 6: \\ Alternative Measures of Settlement and Litigation}
Alternative dependent variables (see text for explanation):
(A) Divorces by agreement/total divorces
(B) Divorces by agreement, conciliation, or settlement/total divorces
(C) (Total divorces less court filings)/total divorces
(D) Litigated divorces/total divorces
(E) Custody petitions/total divorces

\begin{tabular}{|c|c|c|c|c|c|}
\hline \multicolumn{6}{|l|}{ Panel I } \\
\hline Savings PC & $\begin{array}{l}-1.48^{*} \\
(1.70)\end{array}$ & $\begin{array}{l}-.339 * * \star \\
(2.69)\end{array}$ & $\begin{array}{l}-5.64^{\star \star \star} \\
(3.89)\end{array}$ & $\begin{array}{l}.345^{*} \\
(2.66)\end{array}$ & $\begin{array}{l}.020 \\
(0.02)\end{array}$ \\
\hline Adv to High Sch & $\begin{array}{l}-.010^{* * *} \\
(4.08)\end{array}$ & $\begin{array}{l}-.0008^{* *} \\
(2.26)\end{array}$ & $\begin{array}{l}-.014^{* * *} \\
(3.57)\end{array}$ & $\begin{array}{l}.0007^{*} \\
(1.96)\end{array}$ & $\begin{array}{l}.004 \\
(1.49)\end{array}$ \\
\hline Adj R2 & .26 & .16 & .33 & .14 & .01 \\
\hline \multicolumn{6}{|l|}{ Panel II } \\
\hline Dependent Variable & : A. & B. & C. & D. & E. . \\
\hline Savings PC & $\begin{array}{l}-.149 \\
(0.12)\end{array}$ & $\begin{array}{l}-.212 \\
(0.93)\end{array}$ & $\begin{array}{l}-3.87 \\
(1.65)\end{array}$ & $\begin{array}{l}.188 \\
(0.78)\end{array}$ & $\begin{array}{l}.278 \\
(0.15)\end{array}$ \\
\hline Adv to High Sch & $\begin{array}{l}-.003 \\
(1.33)\end{array}$ & $\begin{array}{l}-.0008^{*} \\
(1.74)\end{array}$ & $\begin{array}{l}-.008^{*} \\
(1.78)\end{array}$ & $\begin{array}{l}.0007 \\
(1.46)\end{array}$ & $\begin{array}{l}.0006 \\
(0.18)\end{array}$ \\
\hline Voter turn out & $\begin{array}{l}-.0004 \\
(0.66)\end{array}$ & $\begin{array}{l}-.00004 \\
(0.37)\end{array}$ & $\begin{array}{l}.0008 \\
(0.74)\end{array}$ & $\begin{array}{l}-.000 \\
(0.01)\end{array}$ & $\begin{array}{l}-.001 \\
(0.85)\end{array}$ \\
\hline Volunteer work & $\begin{array}{l}-.0008 \\
(0.97)\end{array}$ & $\begin{array}{l}-.0001 \\
(0.64)\end{array}$ & $\begin{array}{l}-.003^{*} \\
(1.91)\end{array}$ & $\begin{array}{l}.0001 \\
(0.62)\end{array}$ & $\begin{array}{l}.003 * * \\
(2.30)\end{array}$ \\
\hline Unemployment & $\begin{array}{l}-.010^{*} \\
(1.86)\end{array}$ & $\begin{array}{l}-.001 \\
(1.57)\end{array}$ & $\begin{array}{l}-.010 \\
(1.05)\end{array}$ & $\begin{array}{l}.001 \\
(1.25)\end{array}$ & $\begin{array}{l}-.007 \\
(0.89)\end{array}$ \\
\hline Crime rate & $\begin{array}{l}-.0005 \\
(0.40)\end{array}$ & $\begin{array}{l}-.0002 \\
(0.89)\end{array}$ & $\begin{array}{l}.0009 \\
(0.42)\end{array}$ & $\begin{array}{l}.0002 \\
(0.96)\end{array}$ & $\begin{array}{l}-.001 \\
(0.59)\end{array}$ \\
\hline Illegitimacy & $\begin{array}{l}.027^{* * *} \\
(4.87)\end{array}$ & $\begin{array}{l}.003^{* *} \\
(2.52)\end{array}$ & $\begin{array}{l}.035^{* * *} \\
(3.43)\end{array}$ & $\begin{array}{l}-.003^{* *} \\
(2.45)\end{array}$ & $\begin{array}{l}.008 \\
(0.97)\end{array}$ \\
\hline Population growth & $\begin{array}{l}.144 \\
(1.66)\end{array}$ & $\begin{array}{l}-.0 \odot 3 \\
(\odot .21)\end{array}$ & $\begin{array}{l}-.001 \\
(0.01)\end{array}$ & $\begin{array}{l}.0004 \\
(0.03)\end{array}$ & $\begin{array}{l}-.049 \\
(0.39)\end{array}$ \\
\hline Metropolitan & $\begin{array}{l}.004 \\
(0.54)\end{array}$ & $\begin{array}{l}.0005 \\
(0.37)\end{array}$ & $\begin{array}{l}-.010 \\
(0.74)\end{array}$ & $\begin{array}{l}-.001 \\
(0.41)\end{array}$ & $\begin{array}{l}.007 \\
(0.69)\end{array}$ \\
\hline Adj R2 & .57 & .24 & .52 & .19 & .18 \\
\hline
\end{tabular}

Notes: Coefficients, followed by the absolute value of the t-statistic. All regressions include a constant term. Coefficients on Savings are $x 1000,000 . n=47$. See text for definitions and sources of variables. 
Table 7:

The Effect of Attorneys

\author{
Dependent Variable: Settlement Rate \\ Savings PC \\ $-1.01$ \\ $-1.51^{*}$ \\ $-5.54$ \\ $-2.16^{\star *} .916$ \\ $-1.71^{*}-1.64^{*}$ \\ $(1.17)$ \\ $(1.77)$ \\ $(0.43)$ \\ $(2.27)$ \\ $(1.03)$ \\ $(1.91)$ \\ $(1.84)$ \\ Adv to high sch \\ $(3.02)$ \\ $-.008^{* * *}$ \\ $\left(3008^{* * *}-.007^{* *}\right.$ \\ $-.006^{* * *}$ \\ $-.009 * * *-.009 * * *$ \\ Attorneys PC \\ 14.156 \\ $(3.24)$ \\ $(3.24)$ \\ 3.647 \\ (2.75) \\ (3.21) \\ (3.41) \\ $(0.78)$ \\ $(0.68)$ \\ $(0.58)$ \\ $(0.16)$ \\ $(0.40)$ \\ 10.320 \\ 6.657 \\ Voter turnout \\ $-.001^{* *}$ \\ $(0.44)$ \\ $(0.27)$ \\ Volunteering \\ (2.67) \\ Unemployment \\ -.001 * * \\ (2.02) \\ Crime rate \\ .006 \\ (1.29) \\ Illegitimacy \\ .002 \\ (1.38) \\ Population growth \\ (5.01) \\ Metropolitan \\ .049 \\ $(0.53)$ \\ 006 \\ $(0.78)$ \\ Adj R2 \\ .38 \\ .34 \\ .31 \\ .28 \\ .54 \\ $.26 \quad .26$ \\ Notes: The regression is two-stage least squares, with \\ instruments as explained in text. The table gives the \\ coefficient, followed by the absolute value of the t-statistic. \\ All regressions include a constant term. Coefficients on \\ Savings are $x$ 1000,000. $n=47$. See text for definitions and \\ sources of variables.
}


Table 8:

Correlates of Divorce Rate

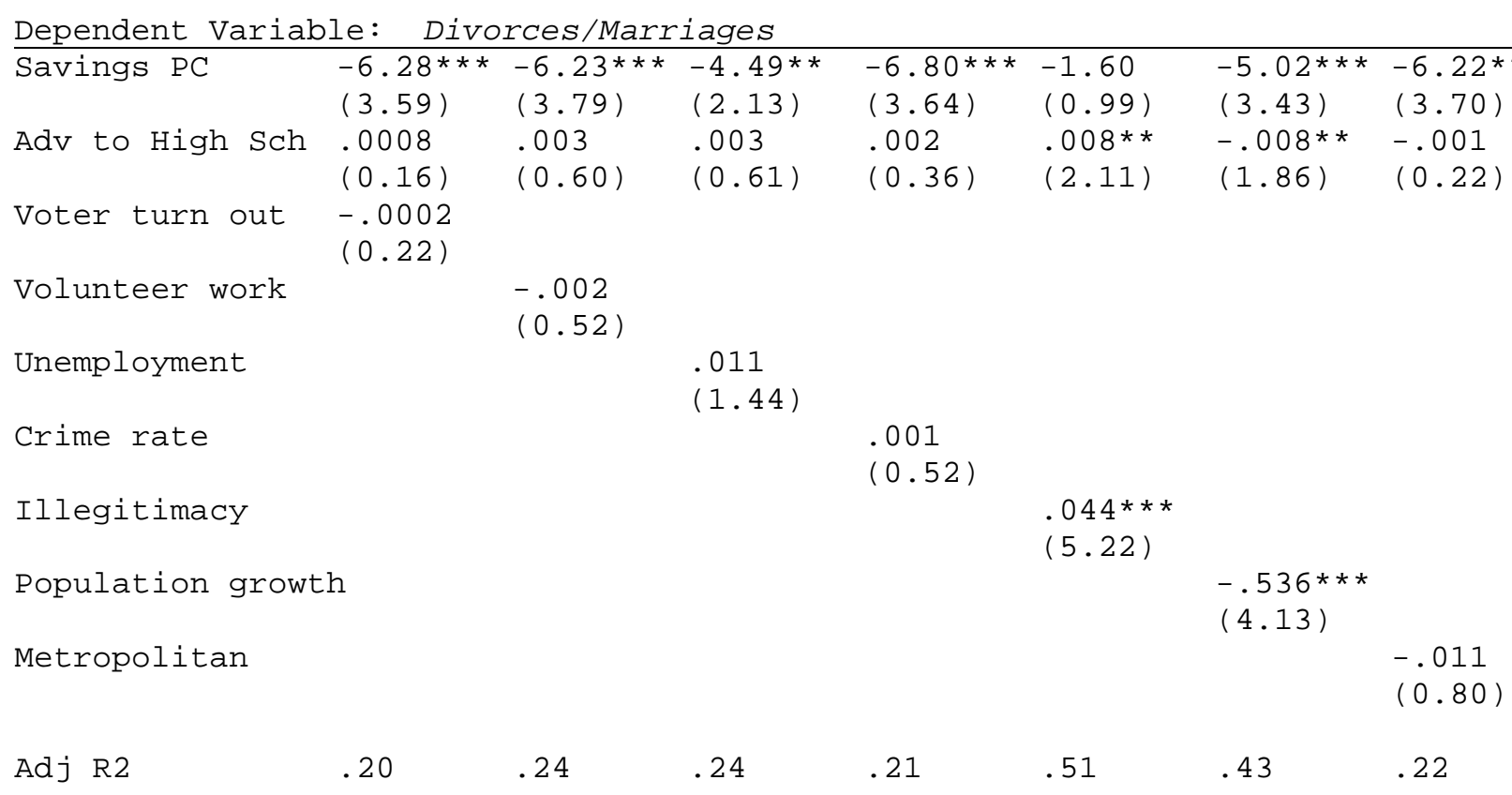

Notes: Coefficients, followed by the absolute value of the t-statistic. All regressions include a constant term. Coefficients on Savings are $x 1000,000 . n=47$. See text for definitions and sources of variables. 
Table 9:

Traffic Accident Litigation

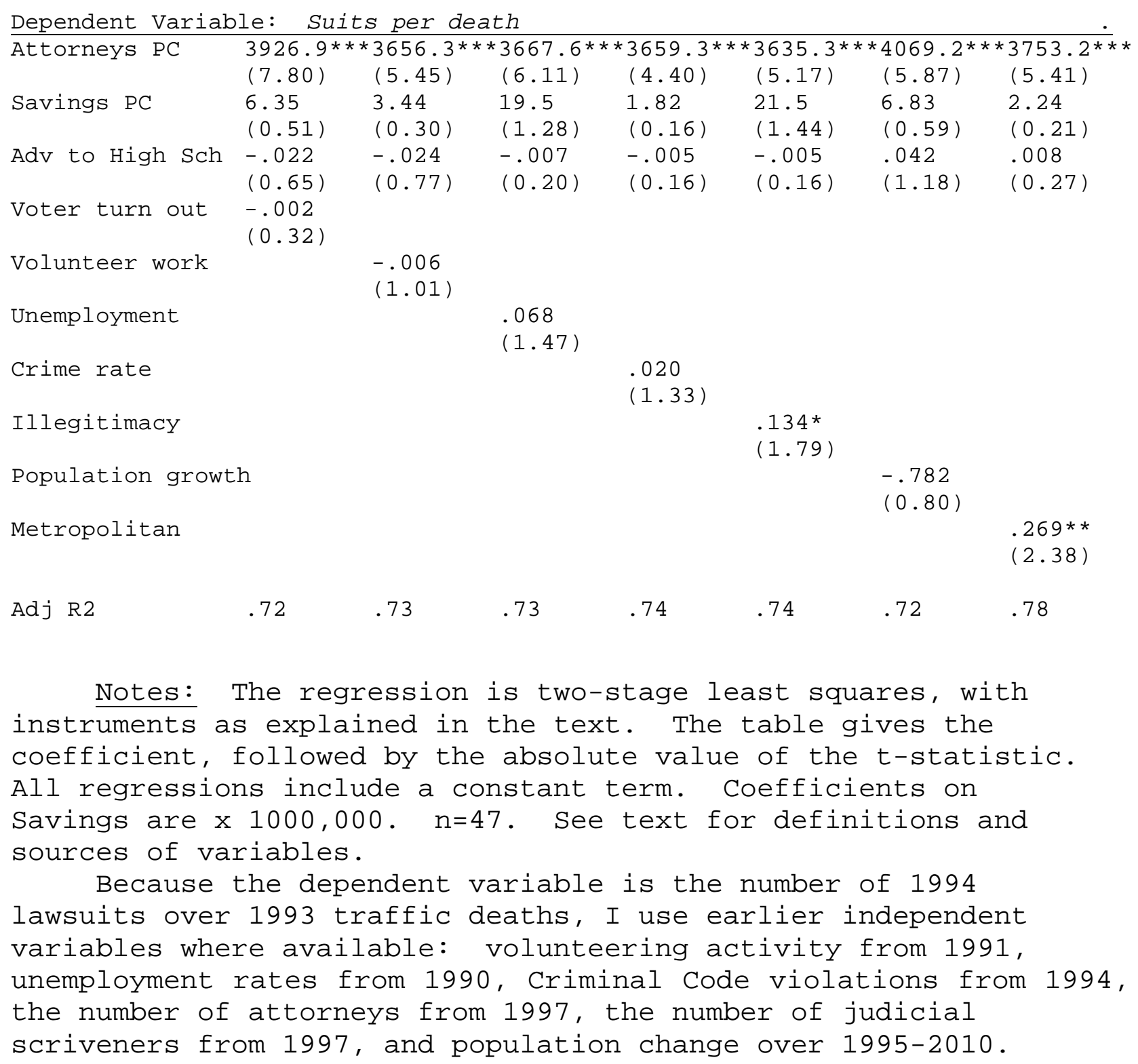


Table 10:

Correlation Coefficients -- Traffic Accident Litigation

\begin{tabular}{|c|c|c|c|c|c|c|}
\hline 1 & itigation & Income & Savings & Unemploy & $t$ Voter & T0 Attorneys \\
\hline Litigation rt| & 1.0000 & & & & & \\
\hline Income PC & $\begin{array}{l}0.4810 \\
0.0006\end{array}$ & 1.0000 & & & & \\
\hline Savings PC & $\begin{array}{l}0.2065 \\
0.1638\end{array}$ & $\begin{array}{l}\odot .6740 \\
\odot .000 \odot\end{array}$ & 1.0000 & & & \\
\hline Unemployment & $\begin{array}{l}\odot .2654 \\
\odot .0714\end{array}$ & $\begin{array}{r}-0.4127 \\
0.0039\end{array}$ & $\begin{array}{r}-0.5049 \\
0.0003\end{array}$ & 1.0000 & & \\
\hline Voter turnout & $\begin{array}{r}-0.2652 \\
0.0716\end{array}$ & $\begin{array}{r}-0.0422 \\
0.7784\end{array}$ & $\begin{array}{l}0.2016 \\
0.1742\end{array}$ & $\begin{array}{r}-0.6815 \\
0.0000\end{array}$ & 1.0000 & \\
\hline Attorneys PC & $\begin{array}{l}0.8573 \\
\odot .000 \odot\end{array}$ & $\begin{array}{l}0.5242 \\
0.0002\end{array}$ & $\begin{array}{l}\odot .1851 \\
\odot .2128\end{array}$ & $\begin{array}{l}0.2079 \\
0.1608\end{array}$ & $\begin{array}{r}-0.2615 \\
0.0759\end{array}$ & 1.0000 \\
\hline
\end{tabular}

Notes: Correlation coefficients, followed by the probability values on the line below. Litigation rate is number of law suits in summary or district court over traffic accidents, 1994, divided by the number of deaths from traffic accidents, 1993. Income PC is for 1996; Unemployment is for 1990; Attorneys PC is for 1997. All other variables are as defined in the text. 
Figure 1: Settlement rate and High School Advancement

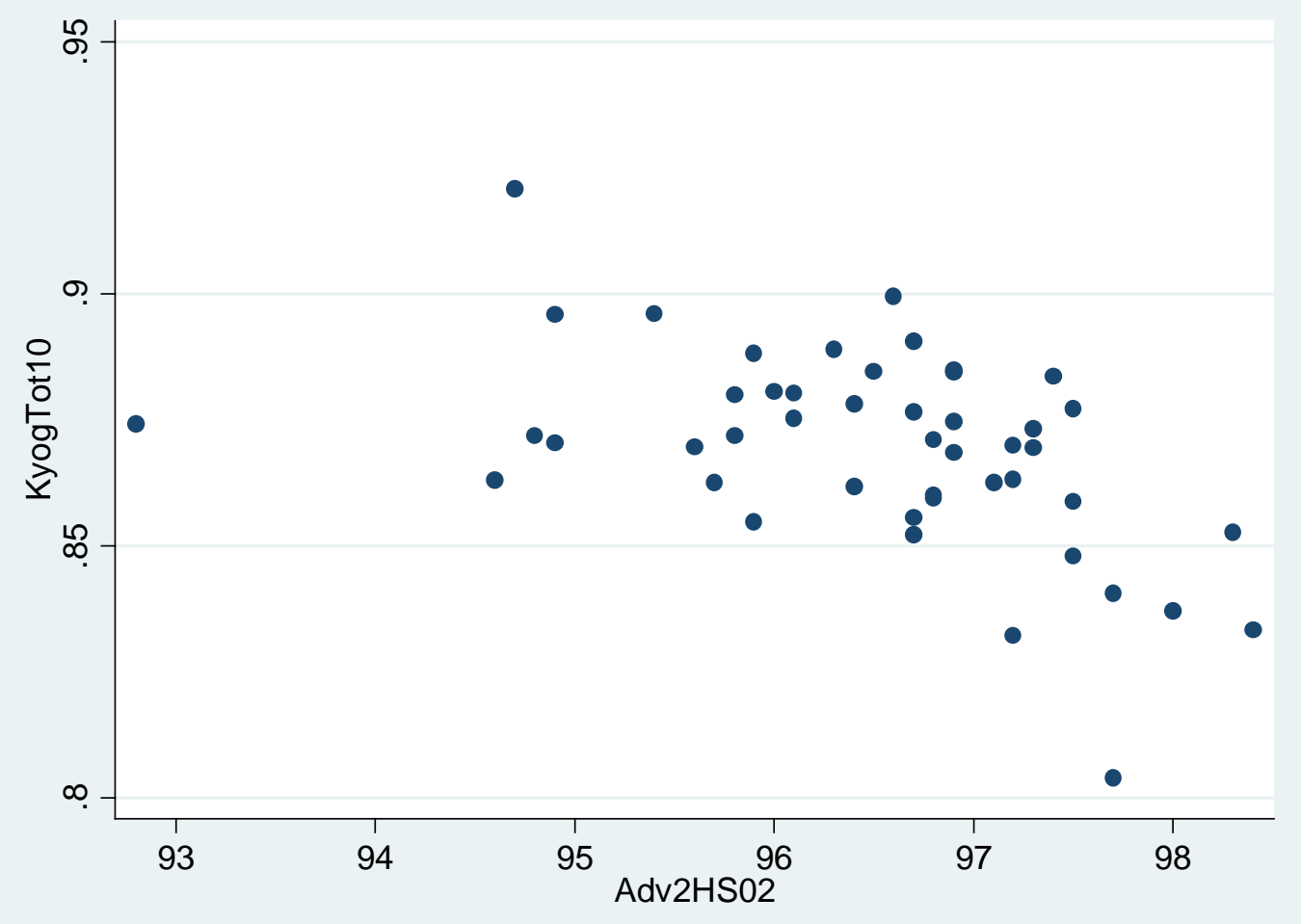

Figure 2: Settlement Rate and Illegitimacy Rate

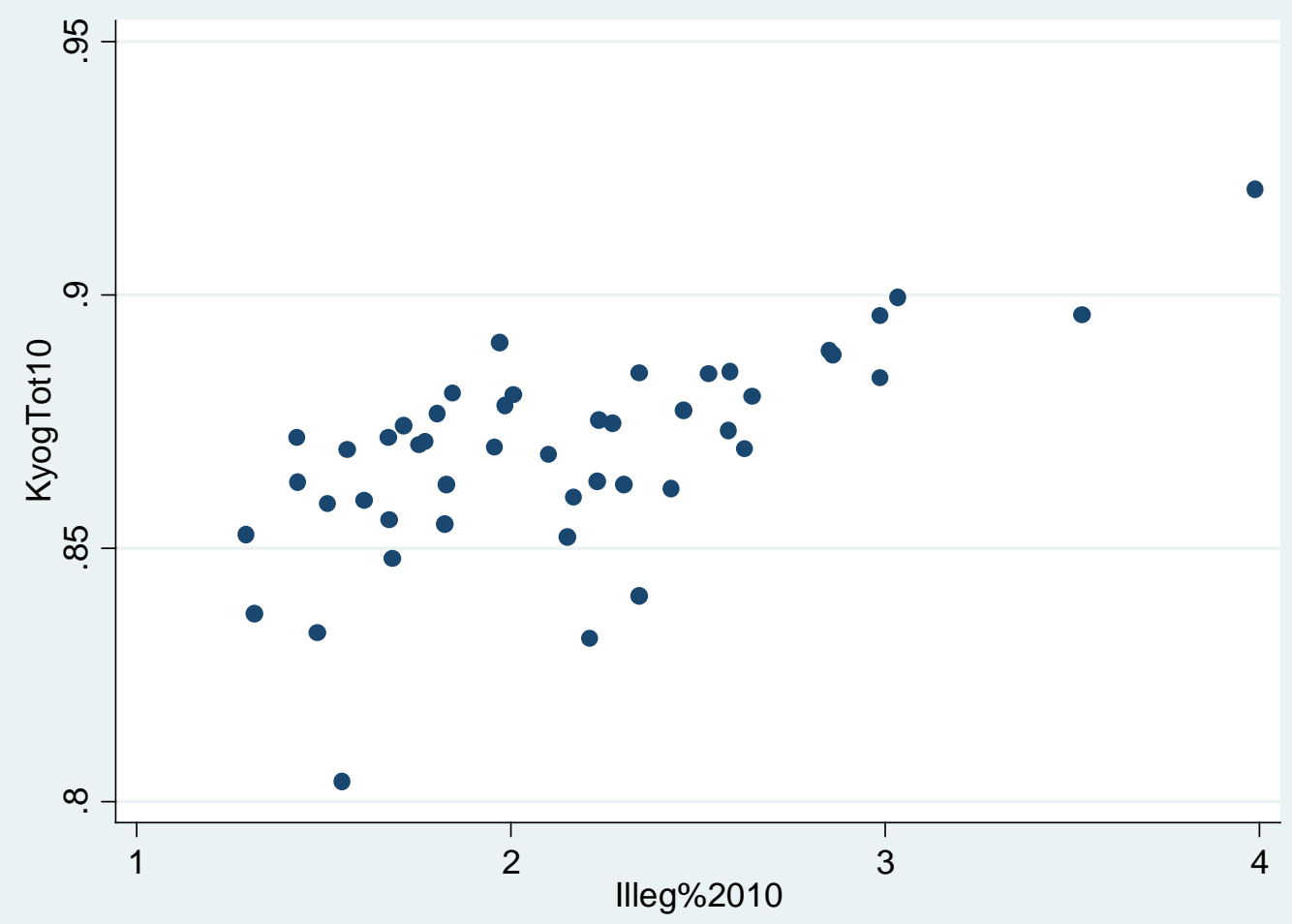


Figure 3: Divorce Settlements and Attorneys

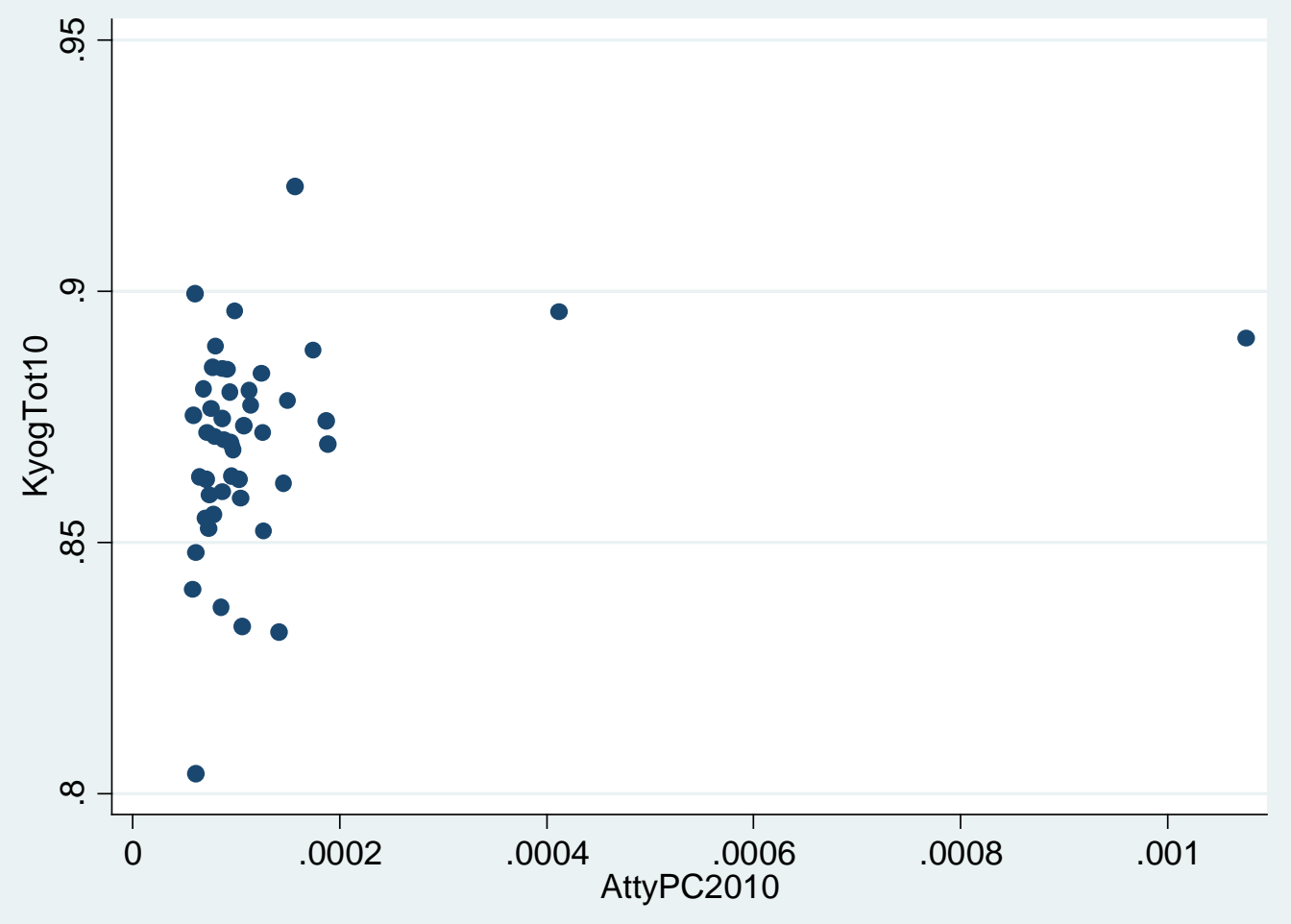

Figure 4: Divorce Rates and Savings

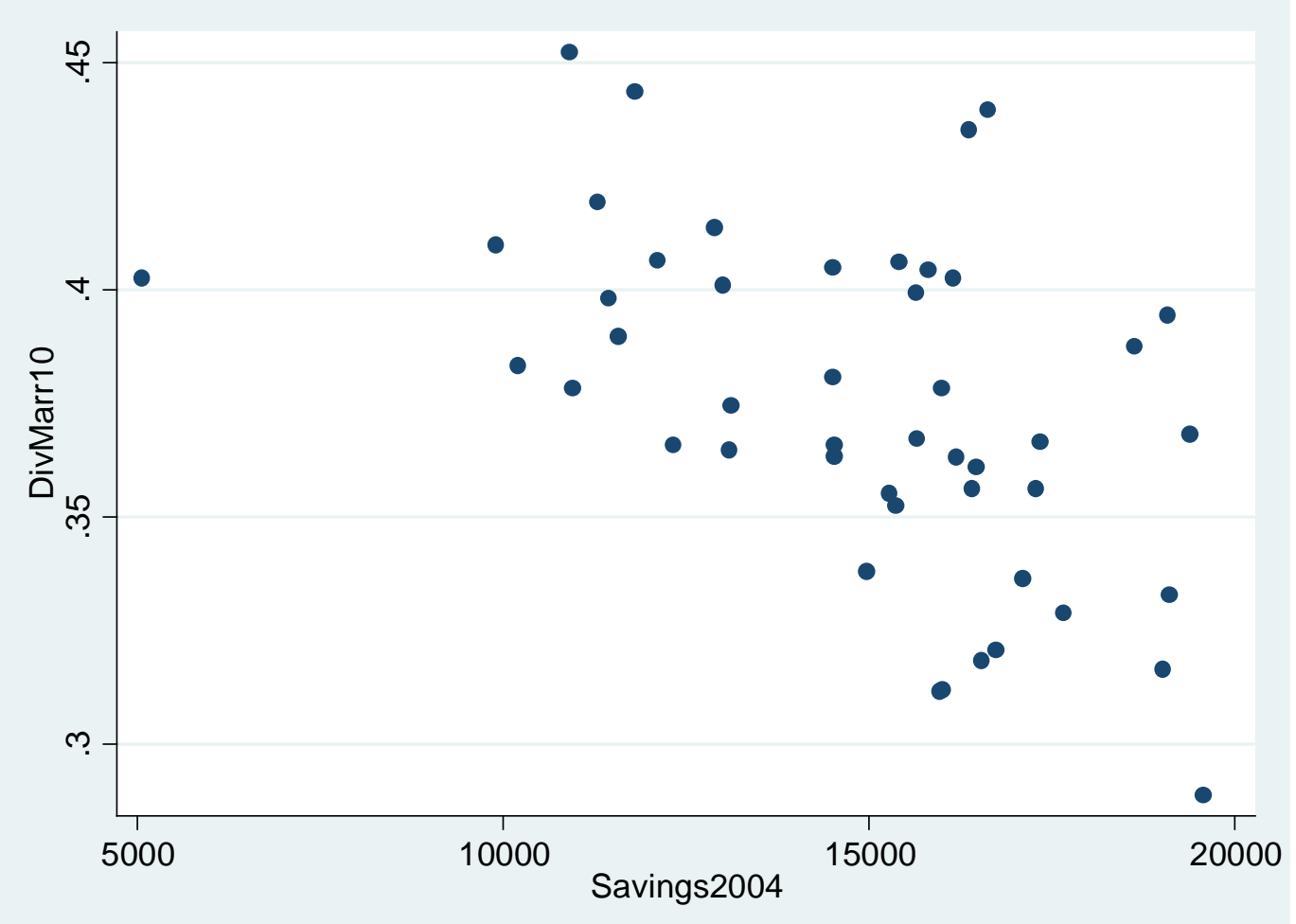


Figure 5: Divorce Rates and Illegitimacy Rate

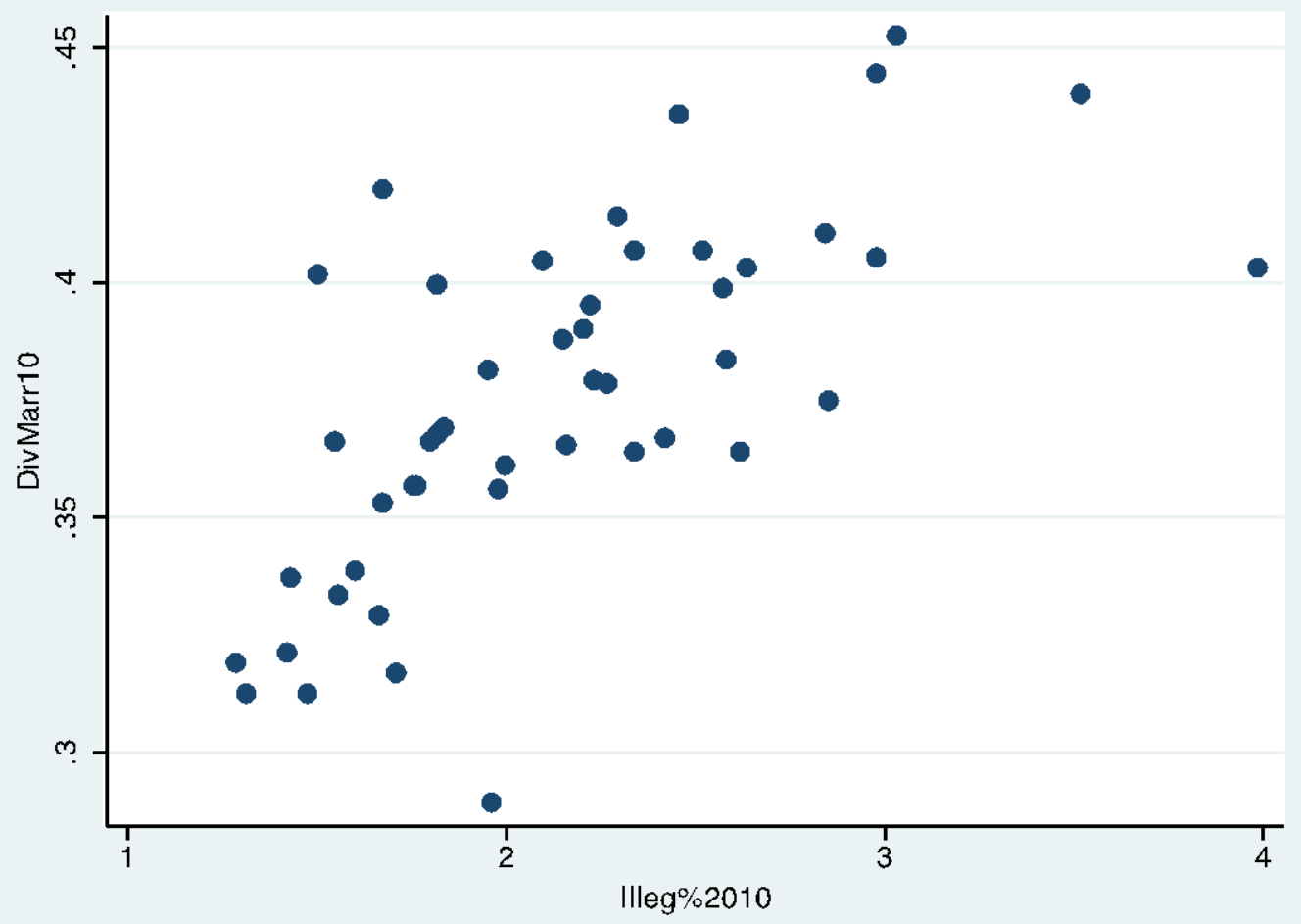

Figure 6: Traffic Accident Litigation and Attorneys

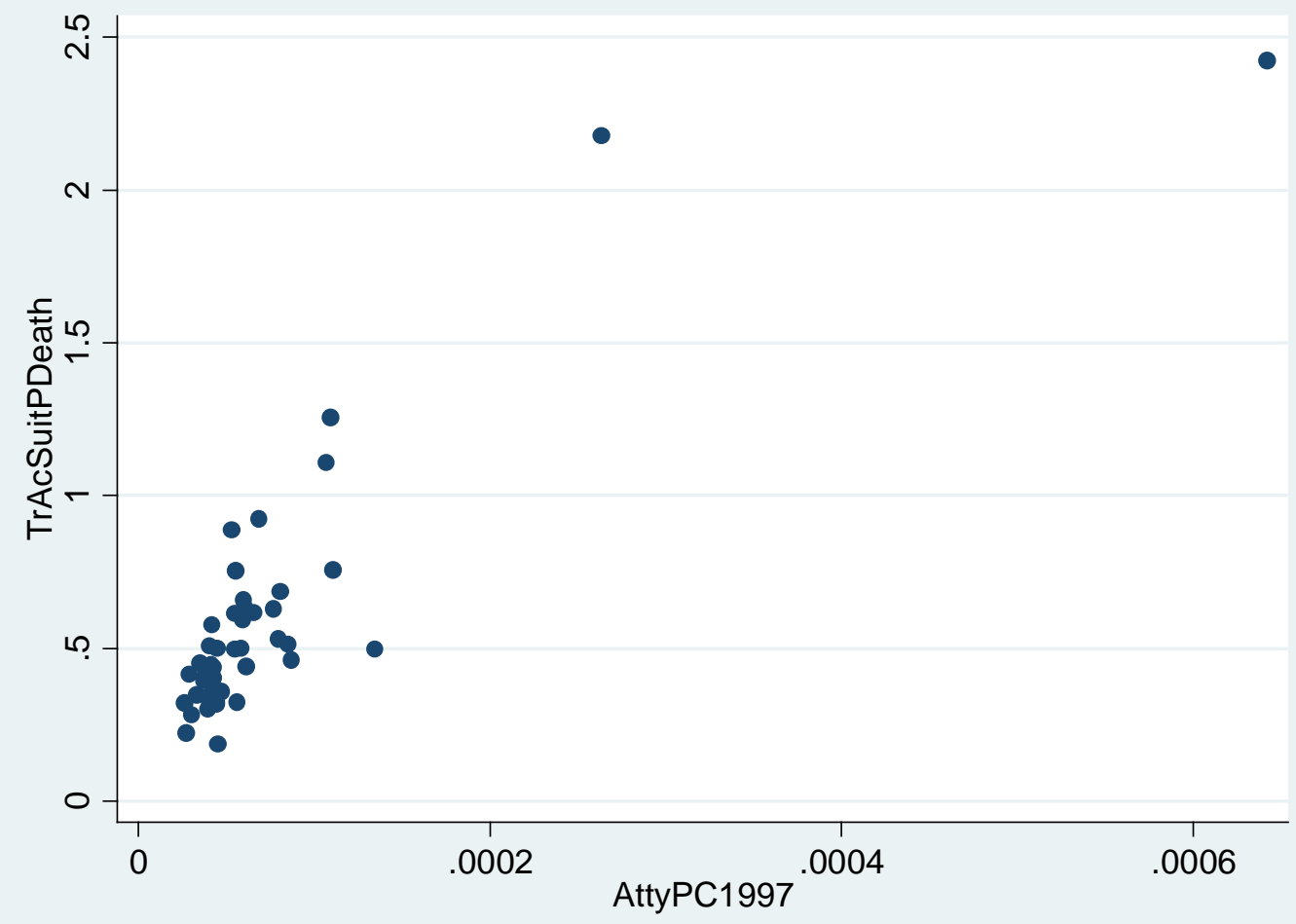




\section{References}

Akerlof, George. 1976. The Economics of Caste and of the Rat Race and Other Woeful Tales. Q.J. Econ. 90, 599-617.

Akerlof, George. 1980. A Theory of Social Custom, of Which Unemployment May Be One Consequence. Q.J. Econ., 94, 749-775.

Becker, Gary S. 1991. A Treatise on the Family: Enlarged Edition. Cambridge: Harvard University Press.

Bryant, Taimie L. 1984. Marital Dissolution in Japan: Legal Obstacles and Their Impact. L. Japan, 17, 73.

Bunka cho. 2008. Shukyo nenkan, Heisei 20 nenban [Religion Annual, 2008]. Tokyo: K.K. Gyosei (pub. 2009).

CAA. See Consumer Affairs Agency.

Eisenberg, Theodore, Sital Kalantry \& Nick Robinson. 2012. Litigation as a Measure of WellBeing. SSRN: 2036194.

Ellickson, Robert C. 1991. Order without Law: How Neighbors Settle Disputes. Cambridge: Harvard University Press.

Ellickson, Robert C. 1998. Law and Economics Discovers Social Norms. J. Legal Stud., 27: 537.

Gekkyu saachi. 2009. Zenkoku kinzoku nensu rankingu [Job Tenure Rankings for the Country]. Available at http://www.ge9.biz/local/kinzoku.html.

Ginsburg, Tom, \& Glenn Hoetker. 2006. The Unreluctant Litigant? An Empirical Analysis of Japan's Turn to Litigation. J. Legal Stud., 35, 31-59.

Hata, Ikuhito. 2009. Okinawasen "shudan jiketsu" no nazo to shinjitsu [The Mystery and Truth of "Mass Suicide" During the Battle of Okinawa]. Tokyo: PHP kenkyu jo.

Homu sho. 2011. Hanzai hakusho [Crimes White Paper]. Tokyo: Homu sho.

Hook, Glenn D. 2003. Responding to Globalization: Okinawa's Free Trade Zone in Microregional Context. In Glenn D. Hook \& Richard Siddle, eds., Japan and Okinawa: Structure and Subjectivity, page 39. London: RoutledgeCurzon.

Katz, Avery. 1996. Taking Private Ordering Seriously. U. Pa. L. Rev., 144: 1745.

Keisatsu cho, ed. 1994. Keisatsu hakusho. Tokyo: Keisatsu cho.

Kosei rodo sho. 2008. Jinko ninshin chusetsu kensu [Number of Abortions]. Available at: http://www.mhlw.go.jp/toukei/saikin/hw/eisei/07/toukei10.html.

Kosei rodo sho. 2010a. Jinko dotai tokei [Vital Statistics of Japan]. Available at: http://www.e-

stat.go.jp/SG1/estat/GL08020103.do?_toGL08020103_\&listID=000001071104 
Kosei rodo sho. 2010b. "Shussei ni kansuru tokei" no gaikyo [Outline of "Statistics Relating to Birth"]. Press release, Dec. 9, 2010.

Landes, William M. 1971. An Economic Analysis of the Courts. J.L. \& Econ., 14, 61.

Lieberman, Jethro K. 1983. The Litigious Society. Basic Books.

Malinowski, Bronislav. 1930. Sex, Culture, and Myth.

Malinowski, Bronislaw. 1930. Parenthood -- The Basis of Social Structure. In Victor F. Calverton \& Samuel D. Schmalhausen, eds., The New Generation. New York: Macaulay.

Mnookin, Robert H. \& Lewis Kornhauser. 1979. Bargaining in the Shadow of the Law: The Case of Divorce. Yale L.J., 88, 950-997.

Monbu kagaku sho. 2005. Shakai kyoiku chosa [Survey of Social Education].

Monbu kagaku sho. 2008. Chiho kyokuikuhi chosa hokokusho [Report of Survey on Local Educational Expenses].

Murray, Charles. 2012. Coming Apart: The State of White America, 1960-2010. New York: Crown Forum.

Nakazato, Minoru, J. Mark Ramseyer \& Eric B. Rasmusen. 2009. Public and Private Firm Compensation Compared: Evidence from Japanese Tax Returns. Korean Econ. Rev., 25, 5.

Nakazato, Minoru, J. Mark Ramseyer \& Eric B. Rasmusen. 2010. The Industrial Organization of the Japanese Bar. J. Empirical Legal Stud., 7, 460.

Nakazato, Minoru, J. Mark Ramseyer \& Eric B. Rasmusen. 2011. Executive Compensation in Japan: Estimating Levels and Determinants from Tax Records. J. Econ. \& Mgmt Strategy, 20, 843.

Nenshu rabo. 2012. Todofukenbetsu nenshu rankingu [Ranking of Annual Income, by Prefecture]. Available at http://nensyu-labo.com/2nd_ken_ranking.htm (for 2008 ime figures).

Nihon ABC Kyokai. 2011. Shinbun hakkosha repoto fukyu ritsu [Diffusion Rate, Newspaper Publisher Report], July-Dec., 2011. Available at: adv.yomiuri.co.jp/yomiuri/busu/busu01b.html.

Nihon bengoshi rengo kai. 2011. Bengoshi hakusho [Attorney White Paper]. Tokyo: Nihon bengoshi rengo kai.

Nihon shiho shoshi rengo kai. 2012. Nihon shiho shoshi rengo kai [Japan Federation of Judicial Scriveners] (home page). Available at: http://www.shihoshoshi.or.jp/association/shiho_shoshi_list.php

Ostrom, Elinor. 1998. A Behavioral Approach to the Rational Choice Theory of Collective Action. Am. Pol. Sci. Rev., 91: 1-22.

Posner, Eric A. 1996. The Regulation of Groups: The Influence of Legal and Nonlegal Sanctions on Collective Action. U. Chi. L. Rev. 63: 133. 
Posner, Richard A. 1973. An Economic Approach to Legal Procedure and Judicial Administration. J. Legal Stud., 2, 399.

Posner, Richard A. 1997. Social Norms and the Law: An Economic approach. Am. Econ. Rev., 87, 365-369 (P\&P).

Posner, Richard A. 1998. Social Norms, Social Meaning, and Economic Analysis of Law: A Comment. J. Legal Stud., 27: 553-565.

Putnam, Robert D. 2000. Bowling Alone: The Collapse and Revival of American Community. New York: Simon \& Schuster.

Ramseyer, J. Mark, \& Minoru Nakazato. 1989. The Rational Litigant: Settlement Amounts and Verdict Rates in Japan. J. Legal Stud., 18, 263.

Ramseyer, J. Mark. 2009. The Effect of Cost Suppression Under Universal Health Insurance on the Allocation of Talent and the Development of Expertise: Cosmetic Surgery in Japan. J. Law \& Econ., 52, 497.

Richard A. Posner \& Eric B. Rasmusen. 1999. Creating and Enforcing Norms, with Special Reference to Sanctions. Int'l Rev. L. \& Econ., 19, 369-382.

Saiko saibansho, ed. 1994. Shiho tokei nempo: 1 Minji, gyosei hen [Annual Report of Judicial Statistics: 1 Civil \& Administrative Cases]. Tokyo: Hoso kai.

Shohisha sho. 2012. Todoufukenbetsu no shihoshoshi su tno kikaku hyo [Comparative Table of Judicial Scrivener and Attorney populations, by Prefecture]. Available at: www.caa.go.jp/seikatsu/shingikai2/kako/spc16/houkoku_c/spc16-houkoku_c-ref_29.html.

Somu sho. 2006. Shakai seikatsu kihon chosa [Basic Survey of Social Life]. Available at: http://www.stat.go.jp/data/shakai/2011/trivia/index.htm\#table3

Somu sho. 2012. Rodoryoku chosa [Survey of Labor Force]. Available at: http://www.stat.go.jp/data/roudou/pref/index.htm (for unemp)

Somusho. 2003. Senkyo kanren shiryo [Materials Related to Elections]. Available at: http://www.soumu.go.jp/senkyo/senkyo_s/data/shugiin44/index.html.

Somusho. 2004. Zenkoku shohi jittai chosa [Survey of National Consumption]. Tokyo: Somusho.

Toba, Ken. 2005. Nihonjin no heikinchi [Average Values for Japanese]. Tokyo: Seikatsu joho sentaa.

Tokyo shoko risaachi. 2004. Zenkoku kogaku nozeisha meibo [National Registry of HighIncome Taxpayers]. CD-ROM version. Tokyo: Tokyo shoko risaachi. 